DRAGAN DAMJANOVIĆ*

\title{
THE HATZINGER FAMILY OF BUILDERS - FROM SZÉKESFEHÉRVÁR, THROUGH OSIJEK, LVIV, AND ZADAR TO VIENNA
}

\begin{abstract}
The article is about the work of Joseph Hatzinger, son of builder Paul (Pál) Hatzinger from Székesfehérvár (Hungary), and Joseph's sons Heinrich and Paul. Joseph worked in Osijek and in Slavonia in the second half of the eighteenth century. In the early nineteenth century, his older son Heinrich spent almost a decade as a professor at the Genie-Akademie (Military Academy of Engineering) in Vienna and designed two important Early Neoclassical churches at Terezin and Josefov fortresses in Bohemia. His younger son Paul, after a brief period as a lecturer at the Genie-Akademie, worked as an engineer in various parts of the Habsburg Monarchy during the first half of the nineteenth century, from Galicia, across Dalmatia, to Vienna and Lower Austria in the final phase of his career. Finally, his great-great-grandson Gusztáv Kasper, the grandson of Paul Hatzinger $\mathrm{Jr}$, became a Hungarian railway engineer at the turn of the twentieth century.
\end{abstract}

Keywords: Baroque, Neoclassicism, Joseph Hatzinger, Heinrich Hatzinger, Paul Hatzinger, Osijek, Zadar, Vienna

\section{INTRODUCTION}

Even though Paul (Pál) Hatzinger is one of the most important Baroque builders in Hungary, it has remained completely unknown to the field of art history in Hungary, Croatia, and other Central European countries that his descendants also became important architects on the territory of the Habsburg Monarchy over a century and a half following his death. In the second half of the eighteenth century, his son Joseph worked in Osijek and in Slavonia; in the early nineteenth century, his older grandson Heinrich spent almost a decade as a professor at the Genie-Akademie (Military
Academy of Engineering) in Vienna and designed two important Early Neoclassical churches at Terezin and Josefov fortresses in Bohemia; during the first half of the nineteenth century, after a brief period as a lecturer at the Genie-Akademie, his younger grandson Paul worked as an engineer in various parts of the Monarchy, from Galicia, across Dalmatia, to Vienna and Lower Austria in the final phase of his career. Finally, his greatgreat-grandson Gusztáv Kasper, the grandson of Paul Hatzinger Jr, became a Hungarian railway engineer at the turn of the twentieth century.

\section{JOSEPH HATZINGER (HACZINGER) AND THE LATE BAROQUE ARCHITECTURE OF SLAVONIA}

The first in the group of these architects, Joseph Hatzinger (Haczinger), was born in Székesfe-

\footnotetext{
* Dragan Damjanović, Art History Department, Faculty of Humanities and Social Sciences, University of Zagreb, Croa-
tia; email: ddamjano@ffzg.hr
}

hérvár on 19 February 1734, the son of Anna Maria and Paul Hatzinger (Senior). ${ }^{1}$ His father was originally from Linz, but he worked almost exclusively in Székesfehérvár and the surrounding areas, where he affirmed himself as the most prolific builder of the mid-eighteenth century. He 
designed the then Jesuit (1741-1751) and the Franciscan church (extended in 1742), restored the parish church, which later became the cathedral church of St Stephen (1743-1744), and built a local hospital (1746-1747). ${ }^{2}$ While Paul Hatzinger's work has been analysed quite thoroughly, it remained unknown that his son belonged to a group of important builders in Slavonia in the late eighteenth century.

There is no doubt as to the fact that he served his apprenticeship with his father, as a 1786 description of Osijek District clearly indicates that he mastered the builder's craft in his hometown 28 years earlier, i.e. around $1758 .{ }^{3}$ It is not known whether he worked somewhere else before Osijek, nor is it known when exactly he moved to the city. However, it can be assumed with fair certainty that Joseph Hatzinger came to live in Osijek in search of work, drawn by opportunities presented by one of the most important fortresses in the southern part of the Monarchy (parts of which were still under construction).

The first mention of his stay can be found in the register of marriages, when he married Rosina Ehrmanin from Osijek in October of 1760. ${ }^{4}$ In this document, he is referred to as Palier, while later in parish registers he was listed as a builder, or an engineer (aedilis), i.e. a civil engineer (aedilis civis). The official records of the General Command of Slavonia (supreme headquarters of the Slavonian Military Frontier) list him as Fortifications Maurermeister ${ }^{5}$ in 1762 , at which time he was working on the construction of military structures in Osijek's fortress. ${ }^{6}$ The very next year, in 1763, the same sources list him as an Enterpreneur, so it is possible that he resigned from military service in the meantime and founded some sort of a private construction company. ${ }^{7}$ Considering, however, that certain documents refer to him as a Fortifications Baumeister again at a later date $(1770),{ }^{8}$ he must have continued working on the construction of various military structures. Other than Johann Schmidt, he was the only mason (Maurermeister) in Osijek, and in 1786 he employed seven journeymen. ${ }^{9}$

Until 1786, the city of Osijek was divided into three autonomous parts - Gornji Grad (Upper Town), Donji Grad (Lower Town), and Tvrda (Inner Town), the last of which was under full military control. At the time, the Roman Catholic parish was dominated by the Jesuits, who held all three parts of Osijek. ${ }^{10}$

Joseph Hatzinger lived with his family in Tvrda, and held the position of town judge (prefect/mayor) there between 1773 and $1778,{ }^{11}$ clear evidence of the high reputation he enjoyed. Thanks to this position, he played an important role in the arrival of Ivan Martin Divald, an important printer and publisher, in Osijek in $1775 .^{12}$

Hatzinger received a plot with a house on it in Tvrda at number 57 as dowry (the street was later named Poštarska, and today the address is 7 Markovićeva street), and he built the new single-storey house that still stands, spending the huge amount of 3,000 forints in the process. ${ }^{13}$ (Fig. 1) Although the designs for this building have not survived, since it was his family house, it was almost certainly designed by Joseph Hatzinger himself. This house is one of the best examples of residential Baroque architecture in Osijek. The first floor façade is the most lavishly decorated, with cartouches and slightly awkward, rustic stucco decorations under the windows.

It is not entirely possible to determine all of which other projects in Tvrda and in the rest of the Military Frontier Hatzinger was involved in, as very few of the documents of the Slavonian Military Headquarters have survived and Osijek's city archives from the eighteenth century have been largely destroyed. ${ }^{14}$ The few surviving sources testify that he was involved in the planning and construction of the chapel in the Tvrda cemetery by $1761,{ }^{15}$ that he leased the city brickworks in $1770,{ }^{16}$ and that he repaired the civil hospital a year later. ${ }^{17}$ Moreover, as a builder, together with the carpenter Mathias Wagner, he received an order from the Town Council of Osijek's Upper Town municipality to build a new town hall in February $1776 .^{18}$

Joseph Hatzinger also participated in the construction of the parish church in Osijek's Lower Town, but it is not possible to establish whether he designed it as well, since only very few fragmented documents of the Jesuit residence in Osijek have survived. ${ }^{19}$ Construction of the present church began between 1758 and 1763, when the tower was raised, followed by the nave and the chancel, which were completed in the period between 1768 and 1775. (Fig. 2)

The tower of this church features a particularly interesting architectural solution - it is a 


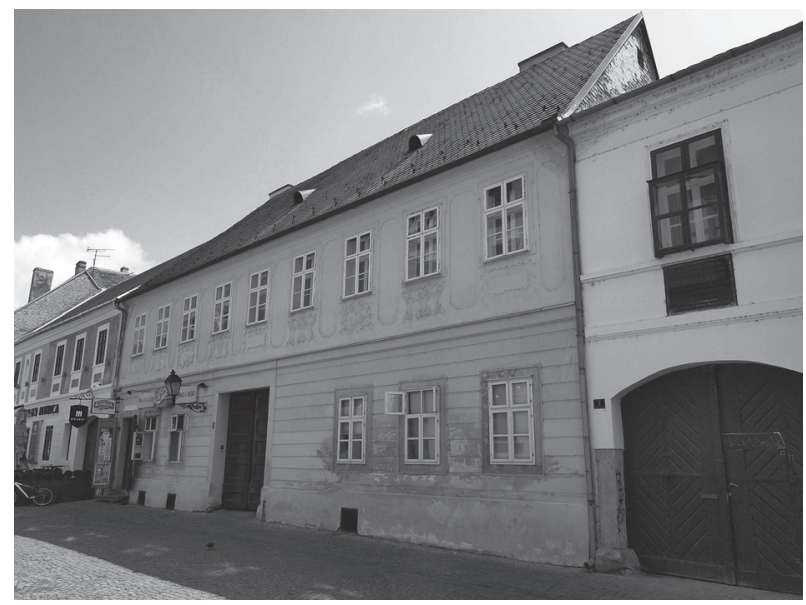

Fig. 1. House of Josef Hatzinger in Osijek's Inner Town (Tvrda/Fortress), built probably in $1760 \mathrm{~s}$ (photo by author, $24^{\text {th }}$ May 2016)

rare example of the influence of Borromini's architectural style in Slavonia. During the placement of the cross on the top of the tower in June 1761, a document was put inside the sphere beneath the cross that provides details about its construction, with references to master builder Ivan Ehrmann from Ochsenhausen, master carpenter Joseph Märckl from Kurpfalz, and his foreman Karl Nebkel from Olomouc in Moravia. The list shows that Osijek, thanks to its role as an important military fortification, was a city that attracted builders and masons from all over Central Europe. Joseph Hatzinger's name does not appear in this document. He was mentioned for the first time regarding the construction of this church in sources dating from 1763, when the parish began to pay him for unspecified work. ${ }^{20}$ Only invoices for the year 1765 clearly indicate that he was being paid "what they owed him for the tower," 21 which means that he took an active part in the construction of this, the oldest part of the church. Whether or not he also designed the tower is, however, impossible to say. The Jesuits could have obtained the design from one of the centres of the order, or it could have been provided by the Archbishop of Esztergom, whose archdiocese at the time also included Osijek.

Joseph Hatzinger's name reappears in accounting records of the parish of Osijek's Lower Town from the 1770s concerning the construction of the nave and the chancel of the church. The invoice book for the year 1771, a time when the construction of the church was at full speed, indicates that the parish owed him

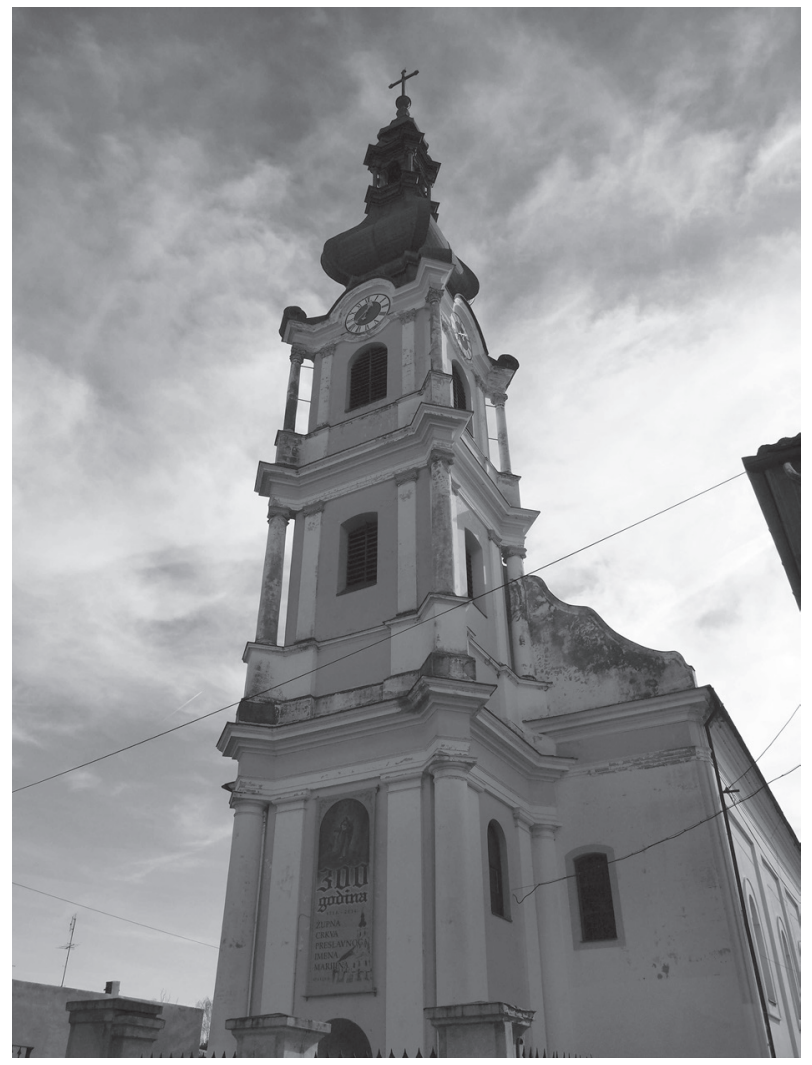

Fig. 2. Parish Church in Osijek's Lower Town, built in 1758-1763, 1768-1775 (photo by author, $15^{\text {th }}$ February 2014)

what was then the considerable amount of 1,000 forints. ${ }^{22}$ Payments to Hatzinger continued until 1781, which shows that he was in charge of the construction of the church. It is certainly possible that it was only then that he received the opportunity to work according to his own design, while he followed another builder's design in the construction of the tower because of its ambitious architectural design, however, no surviving documents confirm this assumption.

Some traces of Joseph Hatzinger's building activities can be found in the area of what were then Virovitica and Syrmia Counties, and the Slavonian Military Frontier. Surviving Virovitica County documents, within whose borders Osijek lay at the time, reveal that he restored the Orthodox church in Čepin. ${ }^{23}$ This church was, however, destroyed during World War II, and very little information survives regarding its appearance. He also designed the old Virovitica County Hall building in Osijek's Upper Town in $1776,{ }^{24}$ but this building was also demolished. After this, he served as master builder for the finishing works on the parish church in Vinkovci from 
1776 to $1778 .^{25}$ Finally, he participated in the construction of one of the largest eighteenth century Habsburg Monarchy fortifications in Arad (today in Romania), however, no precise information exists as to his share in these works. ${ }^{26}$

The Syrmia County Hall in Vukovar is among Joseph Hatzinger's most significant documented works. ${ }^{27}$ He signed the contract for its construction on 26 March 1770. The county hall was built between 1770 and 1773 as a three-winged, U-shaped building. The surviving 1773 design for the palace was signed by Johann Michael Weichmann. $^{28}$ (Fig. 3) However, this design was made when the construction of the building had already been completed, and it shows the actual finished work, which may explain the lack of Hatzinger's signature. As Hatzinger was the only signatory of the construction contract, he almost certainly designed the palace as well. The articulation of the main façade, especially its central part, was quite lavish. Stucco decorations covered the gables of the windows, and to some extent the pillars and the space between the windows as well, which links this building to
Hatzinger's family house in Osijek's Tvrda, on the façades of which stucco also plays a crucial role in articulation (though in a somewhat different form).

The architectural language of the buildings Hatzinger built and possibly designed in the 1760 s and 1770 s was still based entirely upon conservative Baroque templates, which is understandable considering his education. It remains unknown whether or not he subsequently turned to Neoclassicism, since, after resigning as town judge in 1778, he rarely appeared in archive documents. Generally speaking, the main problem with researching Joseph Hatzinger's work is the small number of surviving documents, especially architectural designs, which makes it almost impossible to determine with certainty which buildings he authored, and which he worked on only as a contractor. However, the frequent appearance of his name in surviving documents clearly testifies to the fact that he was an extremely active and highly appreciated builder, the scope of whose work will surely be increased by future research.

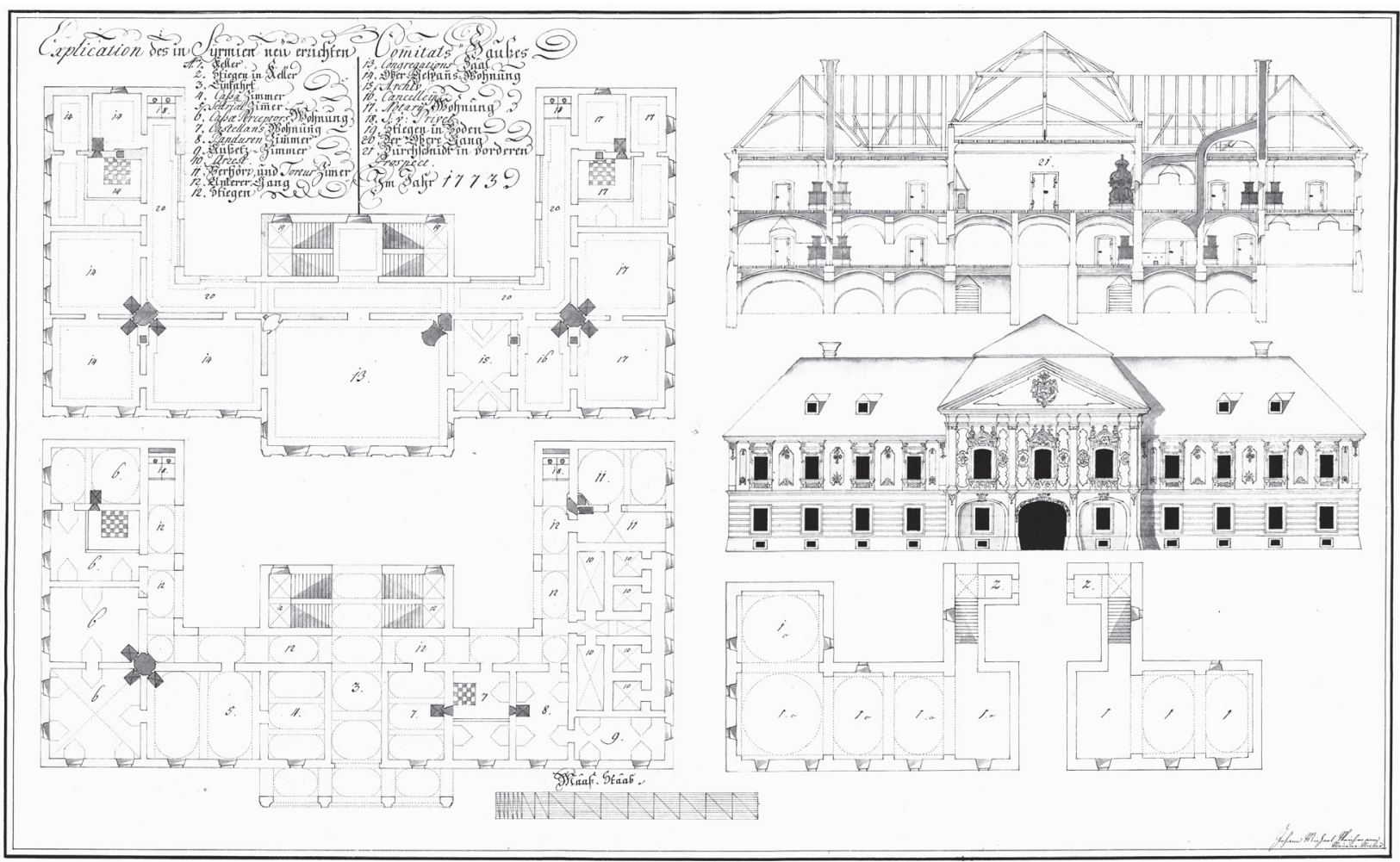

Fig. 3. Johann Michael Weichmann: Syrmia County Hall in 1773; Hrvatski državni arhiv (Croatian State Archives), Zagreb, HR-HDA-12, Hrvatsko kraljevsko vijeće, box CLVI, document 123D ex 1774 


\section{HEINRICH HATZINGER, ARCHITECT AND PROFESSOR OF CIVIL ENGINEERING AT VIENNA'S GENIE-AKADEMIE}

While research on Joseph Hatzinger's architectural work is possible only in fragments, the registers of the parish of Tvrda in Osijek give a quite detailed insight into the basic history of his family. After the death of his first wife in $1768,{ }^{29}$ he married Anna Maria, but no record of this wedding was kept. The married couple had nine children - six sons and three daughters: Joannes Nepomuce (6 May 1771 - ?), Henricus Otto (15 July 1772 - 1809), Josephus Antonius (11 March 1774 - 7 July 1775), Elisabetha Marianna (25 March 1775 - 17 September 1775), Franciscus Xaverius Antonius (17 September 1776 - 3 October 1776), Ignatius Bartholom (20 December 1770 - ?), Josepha Maria Elisabetha (28 April 1781 - 5 August 1782), Paulus (21 January 1783 - Vienna, around 1860?) and Joanna Josepha (15 March 1784 - ?). ${ }^{30}$ The fate of all Joseph Hatzinger's children is not known, except for two of his sons, Heinrich and Paul, who decided to follow in their father's footsteps.

It is not clear whether Joseph Hatzinger remained in Osijek until his death. Even though older literature shows that he died in the city, ${ }^{31}$ his name cannot be found in the death register. As he sold the family house in Tvrda in $1786^{32}$ and his name and surname began appearing among the citizens of Vienna's Vorstadt Alsergrund in the mid-1790s, one can assume that he did move to the Habsburg capital, probably because of his sons' education. This assumption is confirmed by the fact that Joseph Hatzinger's name appears at the same house numbers in Alsergrund (no. 83 and 84) until 1800, as do those of his sons Heinrich and Paul after that. ${ }^{33}$

Both of Joseph Hatzinger's sons studied at the military Ingenieur- (Genie-) Akademie in Vienna, which was one of the best engineering schools in Europe at the time. The choice of an institution of higher education was not only influenced by their father's profession, but also by their childhood in a military fortress, their friendships with commanding officers, and doubtlessly also by the Habsburg Monarchy's involvement in wars against revolutionary France in the late eighteenth century.

As the documents of the Genie-Akademie were partially destroyed in a 1927 fire at the
Vienna's Justizpalast, information concerning the education and work of Heinrich and Paul Hatzinger can be found foremost in Friedrich Gatti's voluminous monograph about the history of the institution, as well as from surviving student rolls. ${ }^{34}$

At the age of 14, in 1790, Heinrich Hatzinger enrolled in the Ingenieur-Akademie, then located at the Theresianum, where he studied until 1793. ${ }^{35}$ Not long after graduating (in 1797 at the latest), he was employed by the Generaldirektorium des Ingenieurskorps und Fortifikationswesens and worked in the department responsible for Vienna's fortifications. ${ }^{36}$ Then, between 1801 and 1809, he held a very important office as a lecturer of Bürgerliche Baukunst at the GenieAkademie, ${ }^{37}$ which he took over from engineer

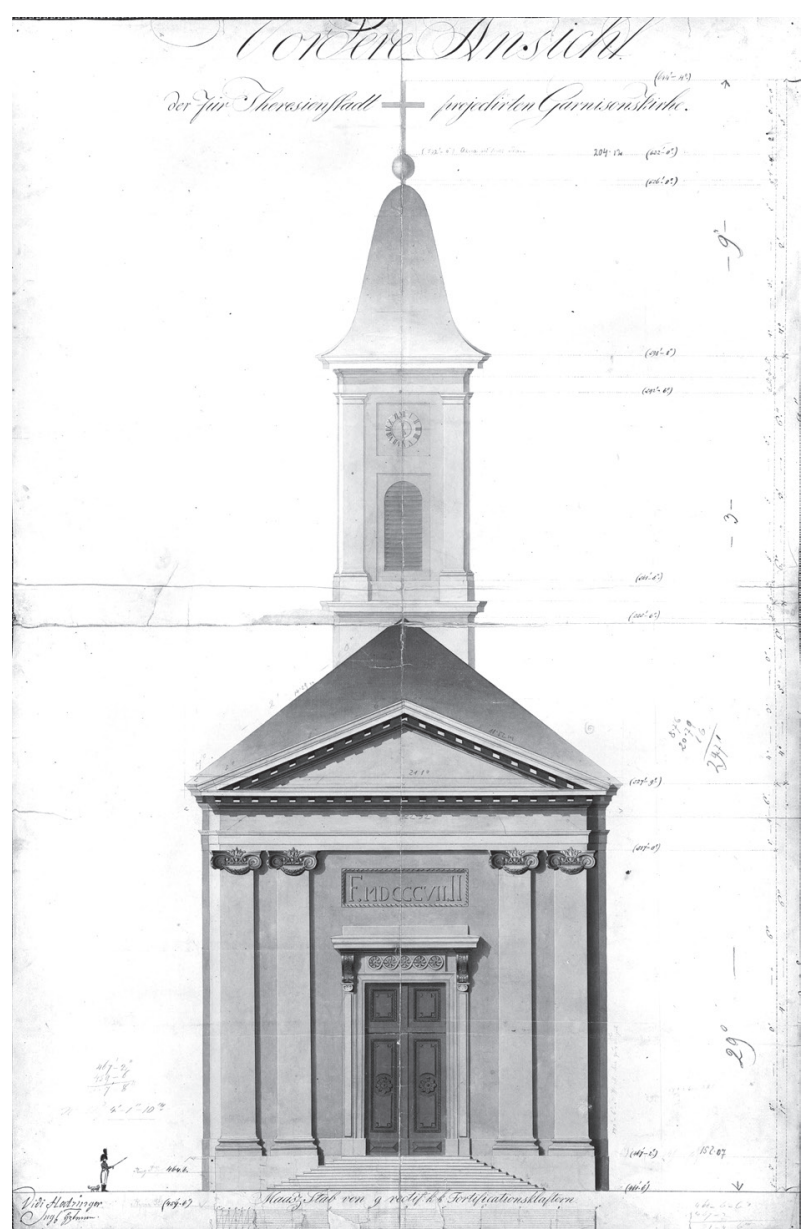

Fig. 4. Heinrich Hatzinger: Design for the main facade of the garrison church in Terezin, ca. 1807; Vojenský ústřední archiv, Praha (Central Military Archives, Prague) 


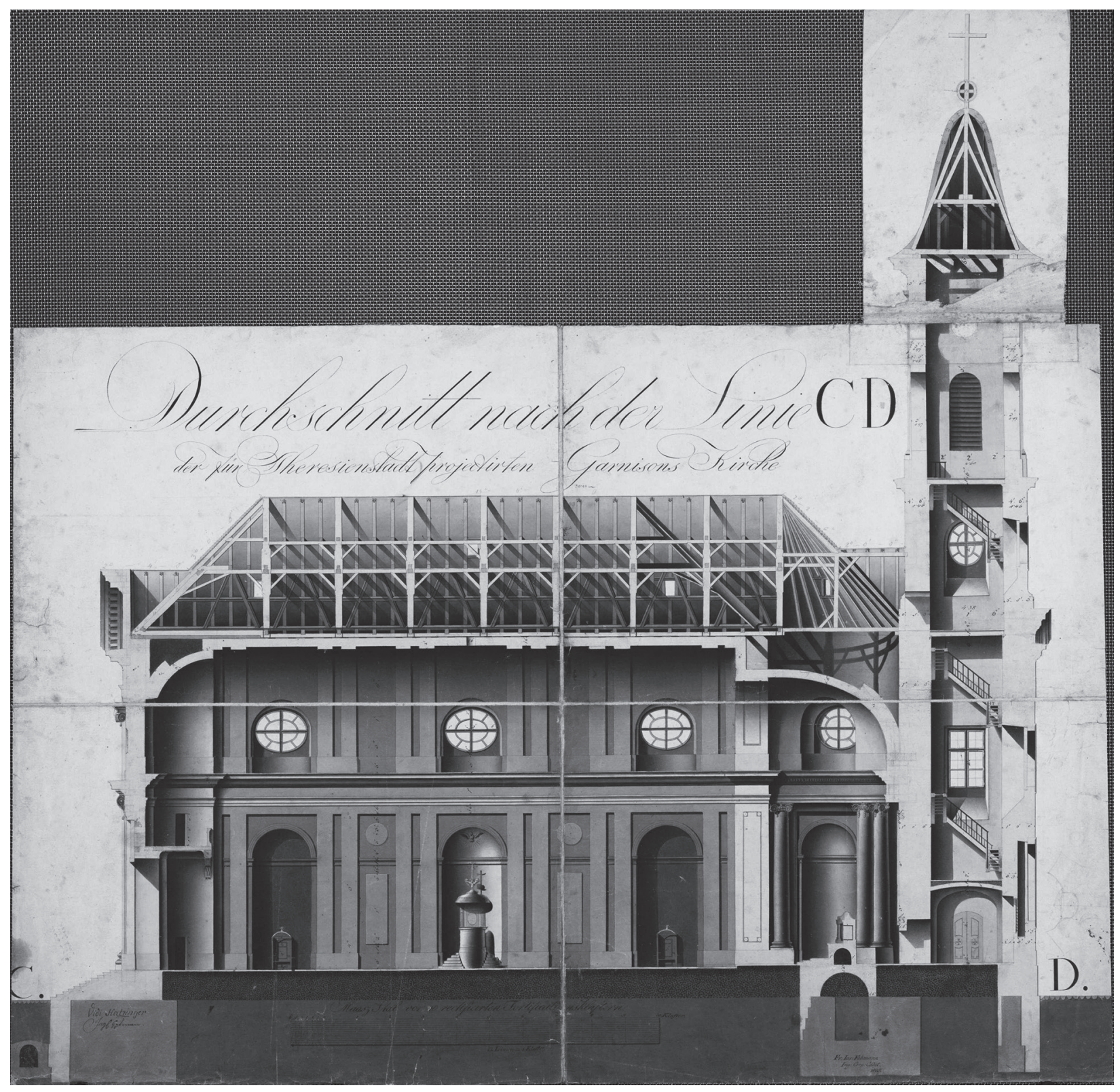

Fig. 5. Heinrich Hatzinger and Franz Josef Fohmann: Cross Section of the garrison church in Terezin, 1805; Vojenský ústřední archiv, Praha (Central Military Archives, Prague)

Josef von Casarotti, whose lectures on the same subject he himself had attended as a student. ${ }^{38}$

Although the academy was created primarily to increase the quality of education of military engineers, and hence also the quality of the fortifications and military buildings they built, it simultaneously taught civil engineering as well. It was part of the programme in semesters 7 and 8, together with the art and tactics of building fortifications, and the construction of waterways, roads, and fortresses. Four basic features of construction were taught: durability (use of materials), comfort, aesthetics, and building economy, as well as the purely technical procedures of design making (which scale to use for designs, how to create budgets, etc.). Special attention was paid to the design of buildings built by the Ingenieurs-Corps (for the deployment of troops and the storage of ammunition and food). ${ }^{39}$

In addition to teaching at the Academy, Heinrich Hatzinger continued to work for military administrative bodies, which had decided to execute an entire string of full-scale construction repairs and additions to the existing fortifications due to military events in Europe. Constant insecurity across the Habsburg Monarchy's borders 


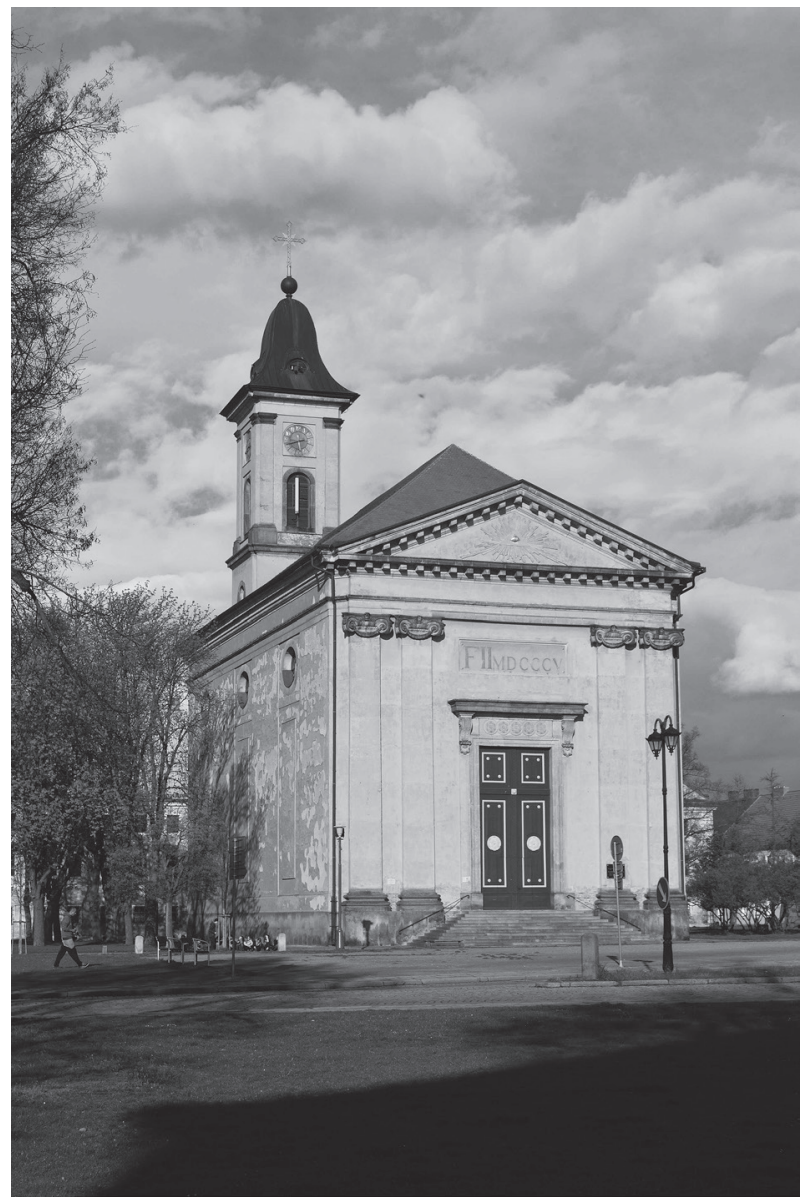

Fig. 6. Heinrich Hatzinger, Julius D'Andreis and Franz Joseph Fohmann: Garrison church in Josefov, 1805-1810 (photo by author, $16^{\text {th }}$ April 2016)

induced Vienna to build two new fortress towns, similar to Hatzinger's home town of Osijek, in Bohemia: Terezin (Teresienstadt), today better known as a notorious Nazi concentration camp, and Josefor (Josefstadt). They were built in the 1780s during the reign of Joseph II, but the slow process of constructing the buildings within the fortresses continued for several more decades. Heinrich Hatzinger, in cooperation with engineers Julius D'Andreis and Franz Joseph Fohmann, designed the central Catholic parish (garrison) churches in both towns using nearly identical architectural designs. ${ }^{40}$

The churches in Josefov (1805-1810), ${ }^{41}$ and Terezin (1806-1810) ${ }^{42}$ belong to a group of important Early Neoclassical buildings built on the territory of the Habsburg Monarchy. (Figs. 4-6) As the only buildings known with certainty to have been built by Heinrich Hatzinger, they clearly show both his stylistic approach and the dominant aesthetics in the military architecture of the

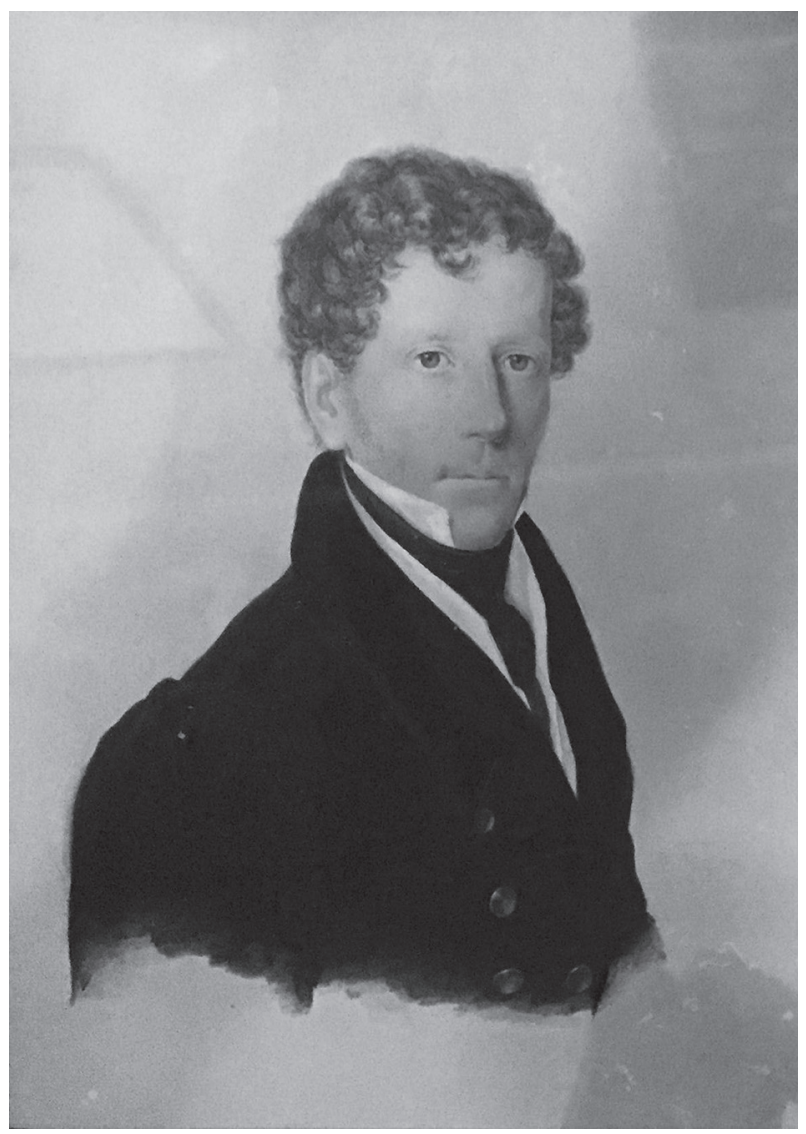

Fig. 7. Portrait of Paul Hatzinger, ca. 1825

(by courtesy of Vilma Thurnay Béláné Schulek

period - their stylistic design is an example of the rationalistic Neoclassicism in the construction of religious and public buildings promoted by the Habsburg rulers starting with Joseph II and lasting until the mid-nineteenth century. Architects were required to design buildings characterised by practicality, durability, and noble simplicity. ${ }^{43}$ Aestheticism was largely pushed aside, so only a few architects succeeded in expressing their originality within this rigid framework. Typified, so-called Normal plans were frequent, and they were used in several places. Therefore, it is no surprise that these two garrison towns feature almost identical churches.

Both churches are single-naved, single-towered buildings with a deep semi-circular apse and a bell tower in the rear of the building. Their front façades are articulated with pairs of Ionic pilasters and crowned with monumental triangular gables, while the side façades are very simply articulated with pilaster strips and oval window openings only. Above the exceptionally high main portal, there are simple inscriptions 


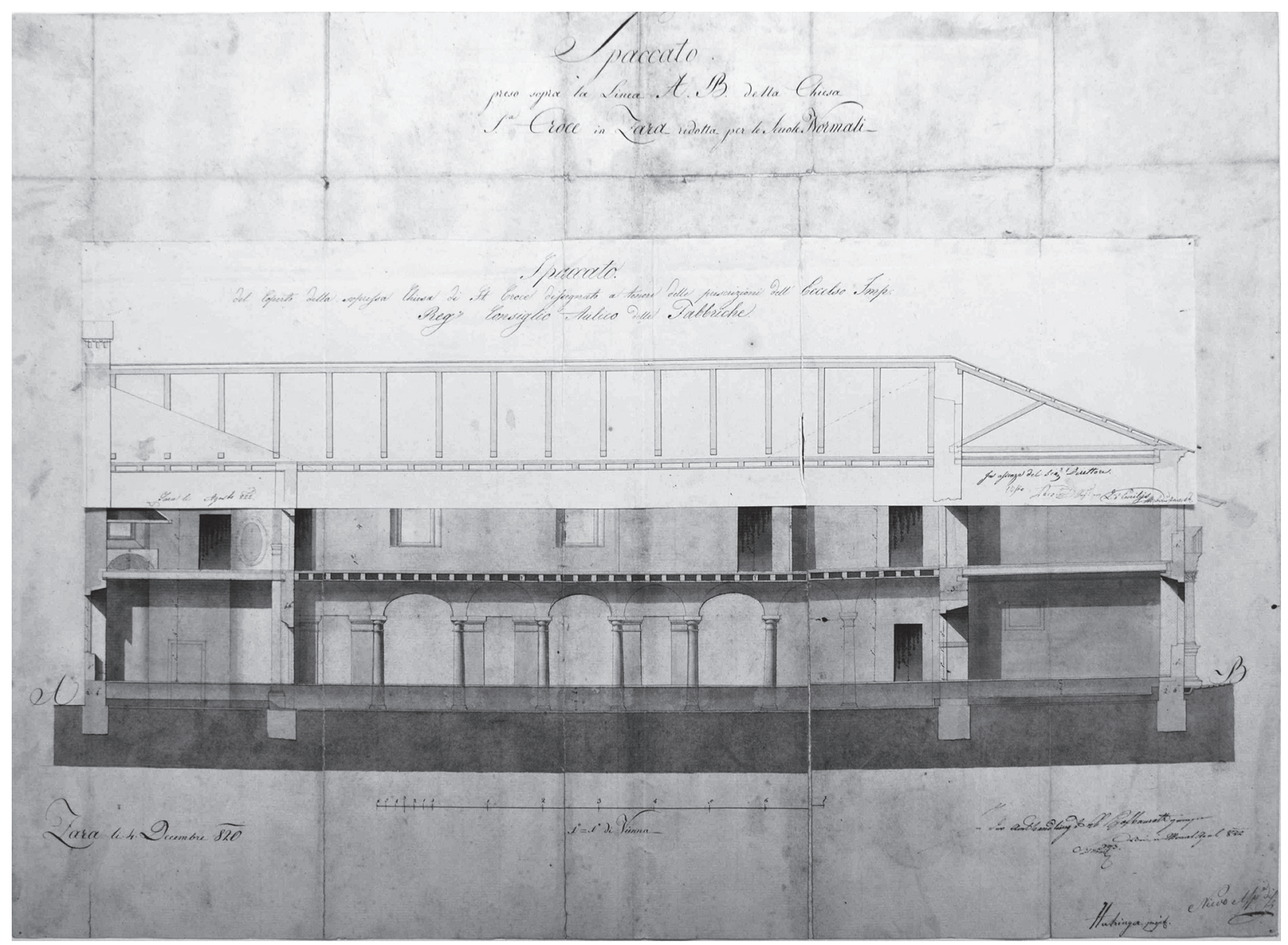

Fig. 8. Paul Hatzinger: Design for the rebuilding of St Thomas' Church in Zadar into an elementary school, 1820; Državni arhiv u Zadru (State Archives in Zadar), HR-DAZD-384, Collection of architectural drawings, sign. VI/E-4

of the year construction began, whereas those in Josefov also contain the ruler's initials (Emperor Francis II). The walls of the nave in the interior are simply articulated with pairs of lesenes, while massive Ionic columns were placed in the chancel. It is not possible to determine how much of this church was designed by Hatzinger and how much by the other two architects.

In addition to the fortresses in Bohemia, Heinrich Hatzinger worked on repairs to various military buildings and the Viennese walls, which were being fortified at the time due to increasing danger from Napoleonic France. However, all his surviving designs are primarily linked to engineering projects. ${ }^{4+}$

The Habsburg wars against Napoleon, which aided Heinrich Hatzinger's career at first, finally cost him his life. As an engineer, he was actively involved in the attempts to defend Vienna from the French in 1809. He worked on fortifying the city to withstand the siege of 5 May 1809, together with all the technical officers present, the senior students of the engineering academy, and Wilhelm Teschenberg, who was also a professor at Genie-Akademie. ${ }^{45}$ Subsequently, as of 8 May, he was involved in securing the passage across the Danube and in digging trenches in the area of Prater. ${ }^{46}$ All attempts at resistance turned out to be futile in the end. Between 10 and 13 May, the French managed to conquer the entire city. Heinrich Hatzinger and Wilhelm Teschenberg were imprisoned during this period - it is not clear whether this occurred because they had worked on the city's defence or because of their technical skills - and taken to Strasbourg, where Heinrich caught typhus and died soon after. ${ }^{47}$

Although only a very small number of his designs have survived, the churches in Terezin and Josefor are indicative of his great potential, the full realisation of which was obstructed by war and by his premature death. His death, however, opened the door to promotion for his brother Paul. 


\section{PAUL HATZINGER, FROM GENIE-AKADEMIE, THROUGH GALICIA AND DALMATIA, TO VIENNA}

The Vienna Engineering Academy, despite being a military institution, continued its work during the siege and afterward, during the French occupation of the city in 1809. However, there was a lack of personnel due to Hatzinger's and Taschenberg's capture, and this problem was partially solved by the appointment of Paul Hatzinger, Heinrich's brother, as the civic architecture professor. ${ }^{48}$ (Fig. 7)

Paul, like his brother, enrolled in the Engineering Academy when he was 14 in 1797, but he remained there for only a year. ${ }^{49}$ He may have continued his schooling elsewhere, but this cannot be confirmed. His employment booklet has survived, however - it is held at the Lower Austria Archive in St. Pölten and shows that his later working life was quite active. When he was 19, he was hired by the Genie-Directorium in Vienna on 1 December 1802 as a master builder of fortifications. He had become a Sappeur by 20 March
1803, and he began working as an Ingenieur Korpskadet at the same institution on 29 March 1805. He was promoted again soon thereafter, on 1 September 1807, to the position of an Oberlieutenant. ${ }^{50}$ This was the position he held in 1809 after his brother died and the French retreated from Vienna, when he was granted the post of professor at the Genie-Akademie, where he began teaching the same course as Heinrich Hatzinger: Bürgerliche Baukunst. He remained at the Academy for a relatively short time, until 1813, when Johann von Kudriaffsky was appointed as the new professor for this course. ${ }^{51}$ Sources are unclear as to his reason for leaving, but it is possible that Paul Hatzinger decided to transfer to the civil service. Of course, the possibility cannot be excluded that, unlike his brother, he did not fulfil the quality conditions set forth by the military.

Throughout the next ten years, Paul Hatzinger worked at various public engineering posts

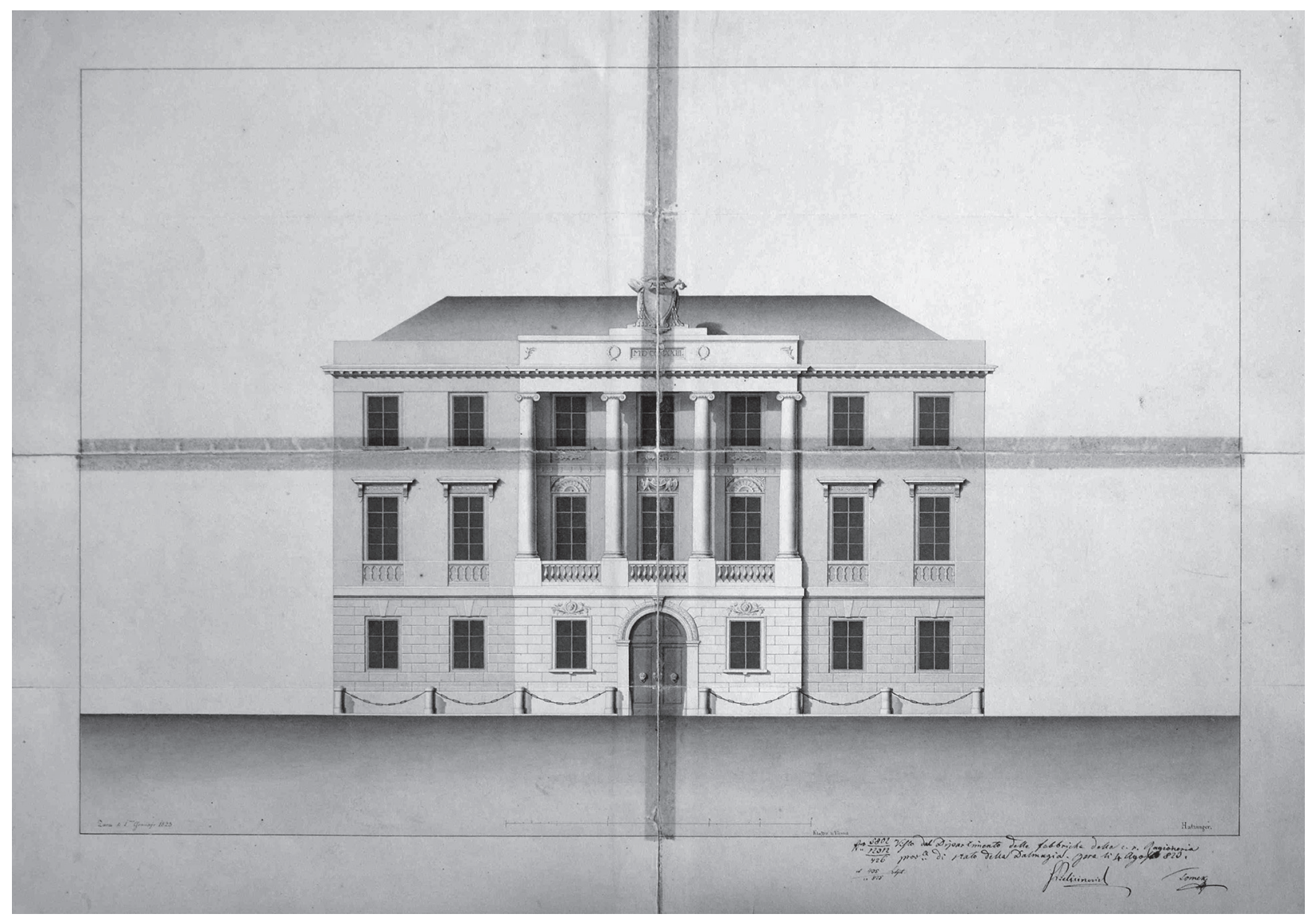

Fig: 9. Paul Hatzinger: Design for the main façade of the archbishopric palace in Zadar, 1823; Državni arhiv u Zadru (State Archives in Zadar), HR-DAZD-384, Collection of architectural drawings, sign. II/D 


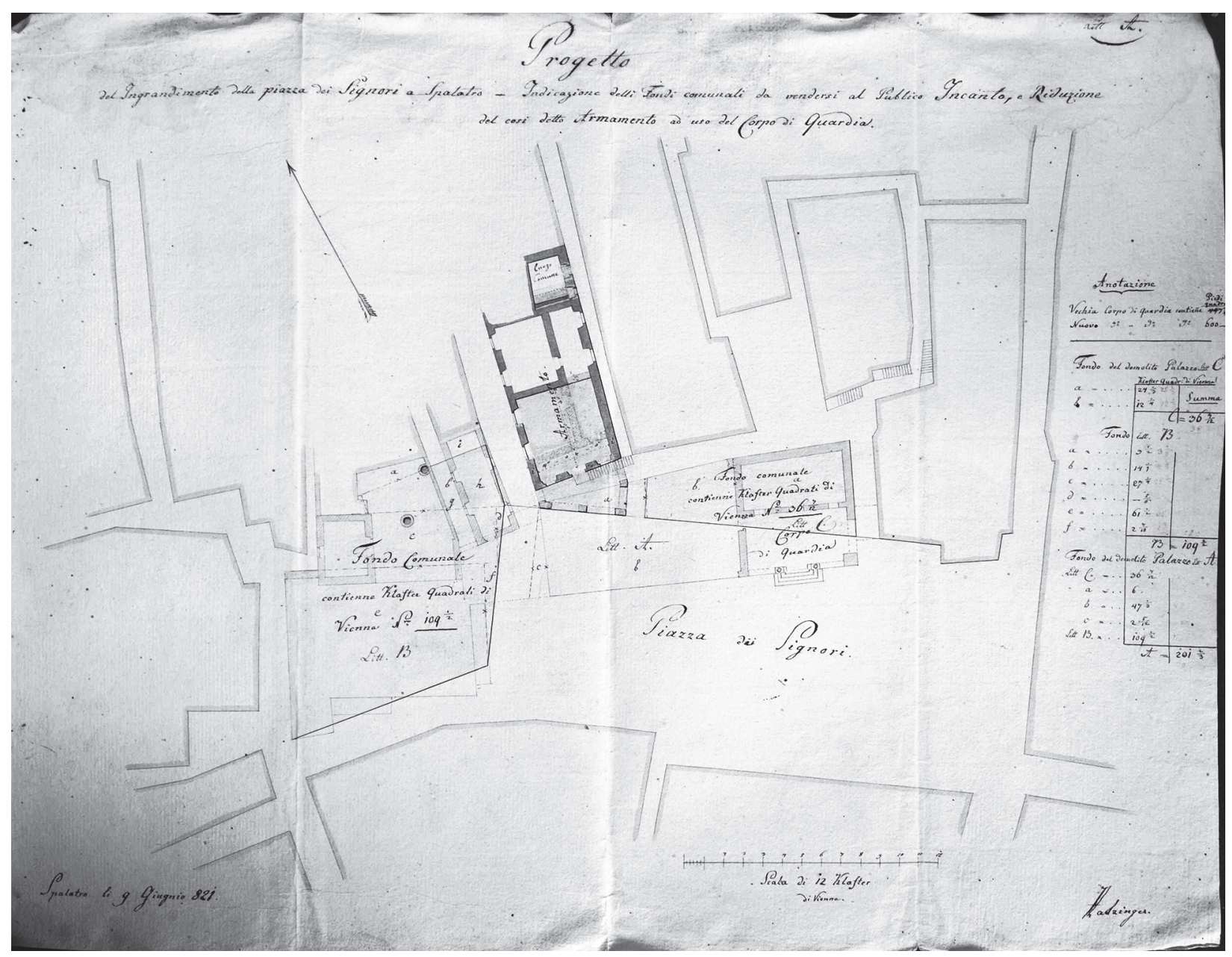

Fig: 10. Paul Hatzinger: Design for the new city square in Split, 1821; Državni arhiv u Zadru

(State Archives in Zadar), HR-DAZD-88, Government of Dalmatia, box 101, document R. N., 1821, file X/1, Nr. 259

in what were the most undeveloped and most distant provinces (from Vienna) in the Habsburg Monarchy at the time. Beginning on 4 January 1813, he was employed by the East Galicia Governorship in Lviv as a Strassenbau-Adjunkt. After five years, he was transferred to the town of Sambor in Galicia on 9 January $1818 .^{52}$ His earliest surviving design is from that time - for a military barrack in the centre of this town.$^{53}$ Only the floor plan has survived, so it is not known what the final design of this building looked like, i.e. what the stylistic characteristics of his works were during this period.

In September of the same year, he moved to the opposite end of the Habsburg Monarchy, to its southernmost province of Dalmatia, where on 22 September 1818 he received the prestigious position of Baudirector of the Dalmatian Government. He began his service on 4 January 1819 and remained there until 5 March $1823 .^{54}$
Habsburg rule in Dalmatia, which Napoleon transferred from the hands of the Venetian Republic into Austrian control for the first time between 1797 and 1806, a fact which was later reconfirmed at the Vienna Congress in 1815, was still taking shape at the time. The Engineering Directorate (Direzione del Genio/Baudirekzion), with Paul Hatzinger at the helm, was one of a number of new institutions formed as part of the Governorship of Dalmatia, which was headquartered in Zadar. He was the only Directorate employee in the beginning, however, 10 experts were employed there by $1822 .^{55}$

After moving to Zadar, Hatzinger was one of the few engineers in Dalmatia with more or less of an education, so he had the opportunity to work even despite the fact that a very small number of civil construction enterprises were undertaken due to the poverty of the province. Even the city of Zadar itself was a very small settlement at the 
time, with around 5,000 citizens, so although it bore the title of capital of Dalmatia, not much construction work was being undertaken there. ${ }^{56}$

Right after moving to Zadar, Hatzinger asked for a special room where he could design his works. ${ }^{57}$ The designs he made during this period prove him to be an extremely versatile and even quite talented architect who designed buildings, roads, channels, and water supply systems, and who drafted master plans and detailed maps of various parts of Dalmatia. While many documents regarding his work in Dalmatia have survived, most of his designs have been lost. The one that stands out among the rare surviving designs is that for the reconstruction of St Thomas'/ Holy Cross Church in Zadar, which was transformed into an elementary school (1820). (Fig. 8) He tried to preserve this desacralized building as much as possible and to merely adapt it for educational purposes. ${ }^{58}$ It is not possible to determine whether he consciously cared for the monument or he simply limited construction works in order to save as much money as possible.

His next important surviving design, for which only the ground plan survives, was for a pre-trial detention facility in Zadar (1822), however, it was never built. ${ }^{59}$ The same is the case with his design for a new city water supply system. ${ }^{60}$

The financial situation in the city also resulted in his extravagant design for an addition to the Archbishop's Palace in Zadar being discarded. Located in the centre of the city, near the Romanesque cathedral and the Pre-Romanesque church of St Donat, this building was supposed to be rebuilt as a two-storey building with a protruding central avant-corps articulated with Ionic columns. ${ }^{61}$ (Fig. 9) The monumental Neoclassical articulation of the main façade was too costly for impoverished Dalmatia, so in the end a much simpler one storey building was constructed in the late 1820s. Though it never came to fruition, this design shows both Hatzinger's talent and his adoption of the architectural language of Neoclassicism.

In addition to Zadar, Hatzinger also designed buildings in other Dalmatian towns. He worked on the Orthodox Seminary in Šibenik, however, his designs have not survived. Furthermore, he actively participated in solving a problem concerning the fate of the Duke's Palace and Communal Palace in Split. It was his evaluation from
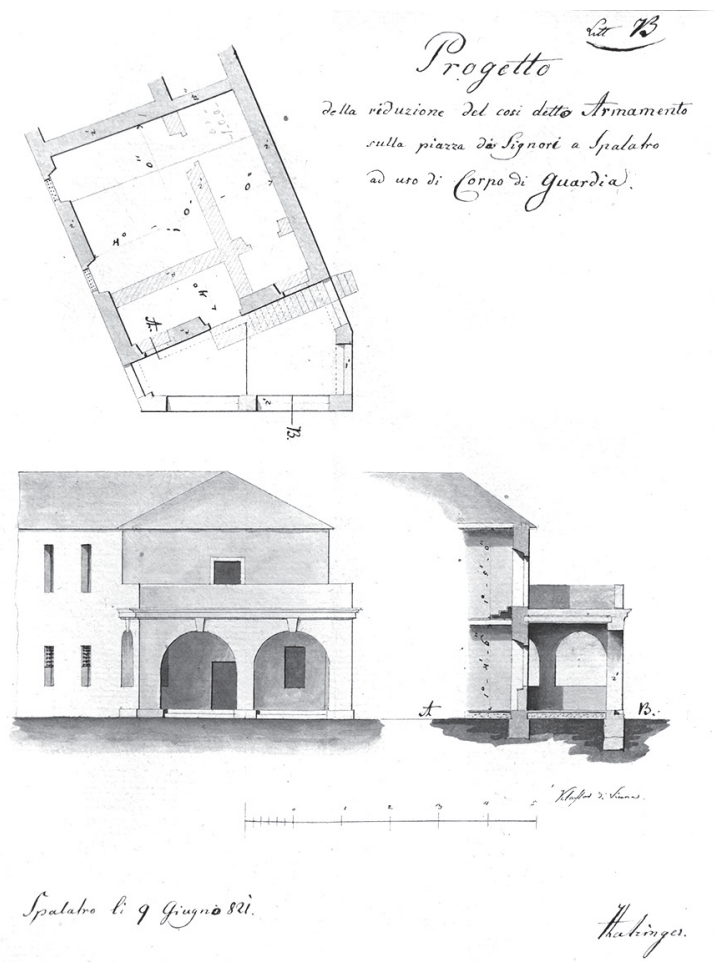

Fig. 11. Paul Hatzinger: Design for adding a lodge to Armamenta building in Split, 1821; Državni arhiv u Zadru (State Archives in Zadar), HR-DAZD-88, Government of Dalmatia, box 101, document R. N., 1821, file X/1, Nr. 259

January 1820 that resulted in the demolition of the majority of the complex of these Gothic palaces due to their extremely poor condition. He pointed out that the demolition of the buildings constituted an excellent opportunity for a largerscale urban development, so he designed a spacious rectangular city square that was to represent a novelty in Split at the time. (Fig. 10) His designs have also survived for the addition of a loggia to the Armamenta building, which would have faced this square with wide, modest Neoclassical arches. ${ }^{62}$ (Fig. 11) Due to a lack of funds, these projects never came to fruition either.

Hatzinger left his deepest mark on Dalmatia in the area of pure engineering projects, mostly road construction. He worked on the designs for the road from Zadar through Obrovac and on towards Mali Alan and continental Croatia. one of the key transport projects of the Austrian government, which connected Dalmatia with the rest of the Habsburg Monarchy over the Velebit mountain range. The construction of this road began in 1819, and did not end until 1832. Hatzinger worked with Josip Kajetan Knežić, ${ }^{63}$ one of the most important bridge and road builders 


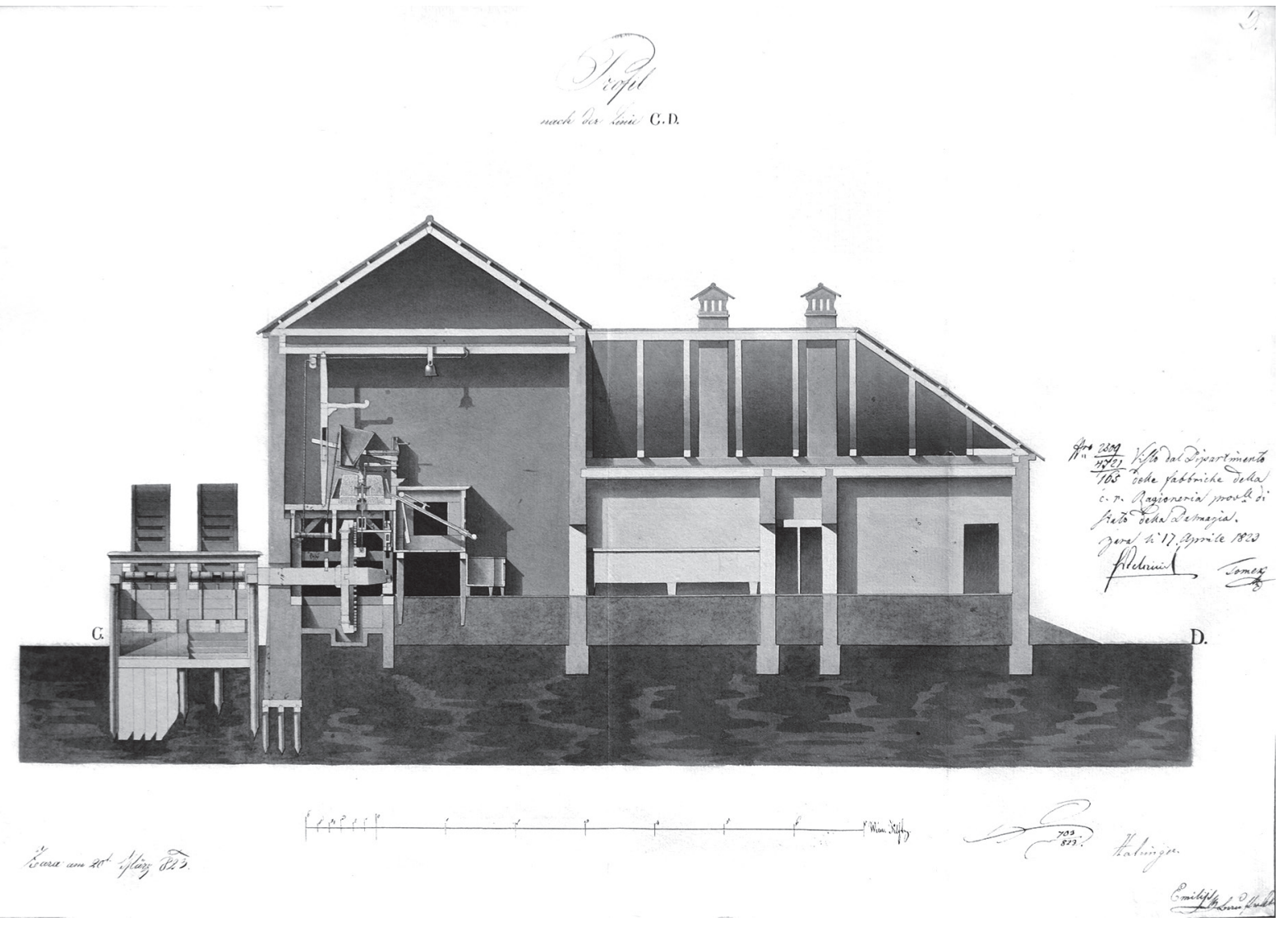

Fig. 12. Paul Hatzinger: Design for a watermill on Krka river; Državni arhiv u Zadru (State Archives in Zadar), HR-DAZD-88, Government for Dalmatia, box 125, file XI/3., 1252 ex 1823

in Croatia and the Habsburg Monarchy. Hatzinger also worked on the construction of roads towards Kistanje and in Krivošije, as well as on the regulation of the courses of the Čikola and Krka rivers, ${ }^{64}$ also designing a watermill on the Krka river. $^{65}$ (Fig. 12) Furthermore, he created a series of maps for the Neretva $(1820)^{66}$ and Zadar $(1821)^{67}$ areas, as well as a map of all Dalmatia by the order of Franz Josef Saurau, Austrian Minister of the Interior, in 1819. ${ }^{68}$

Following a Royal decree issued on 5 March 1823, ${ }^{69}$ and after having spent four years in Dalmatia and accruing 20 years of working experience, he was appointed as Baudirector of Lower Austria. This was one of the most prestigious positions in the public civil engineering service in the Austrian Empire at the time. Vienna was the centre of Lower Austria, and the engineers from its Directorate for Civil Construction partially controlled public civil construction investments in Vienna itself, mostly in the suburbs (Vorstädte) and in the remainder of this spacious and one of the richest Austrian provinces. In the light of

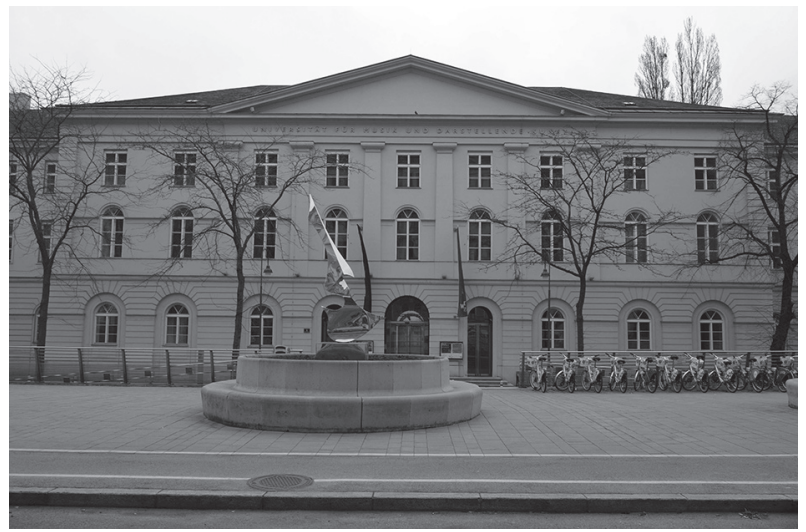

Fig. 13. Johann Fischer (?), Johann Amman (?) and Paul Hatzinger (?): Veterinary Institute (Thierheilinstitut),

Vienna, ca 1823 (photo by author, 13 March 2016)

his new position, Paul Hatzinger also received a larger salary - 2,000 forints per year. But unlike Zadar, there was much stronger architectural competition in Lower Austria. He was no longer a member of a group of scarcely educated builders. At the time, the Viennese architectural scene was dominated by Pietro Nobile, Joseph Kornhäusel, and later by Paul Sprenger, so Hatzinger 


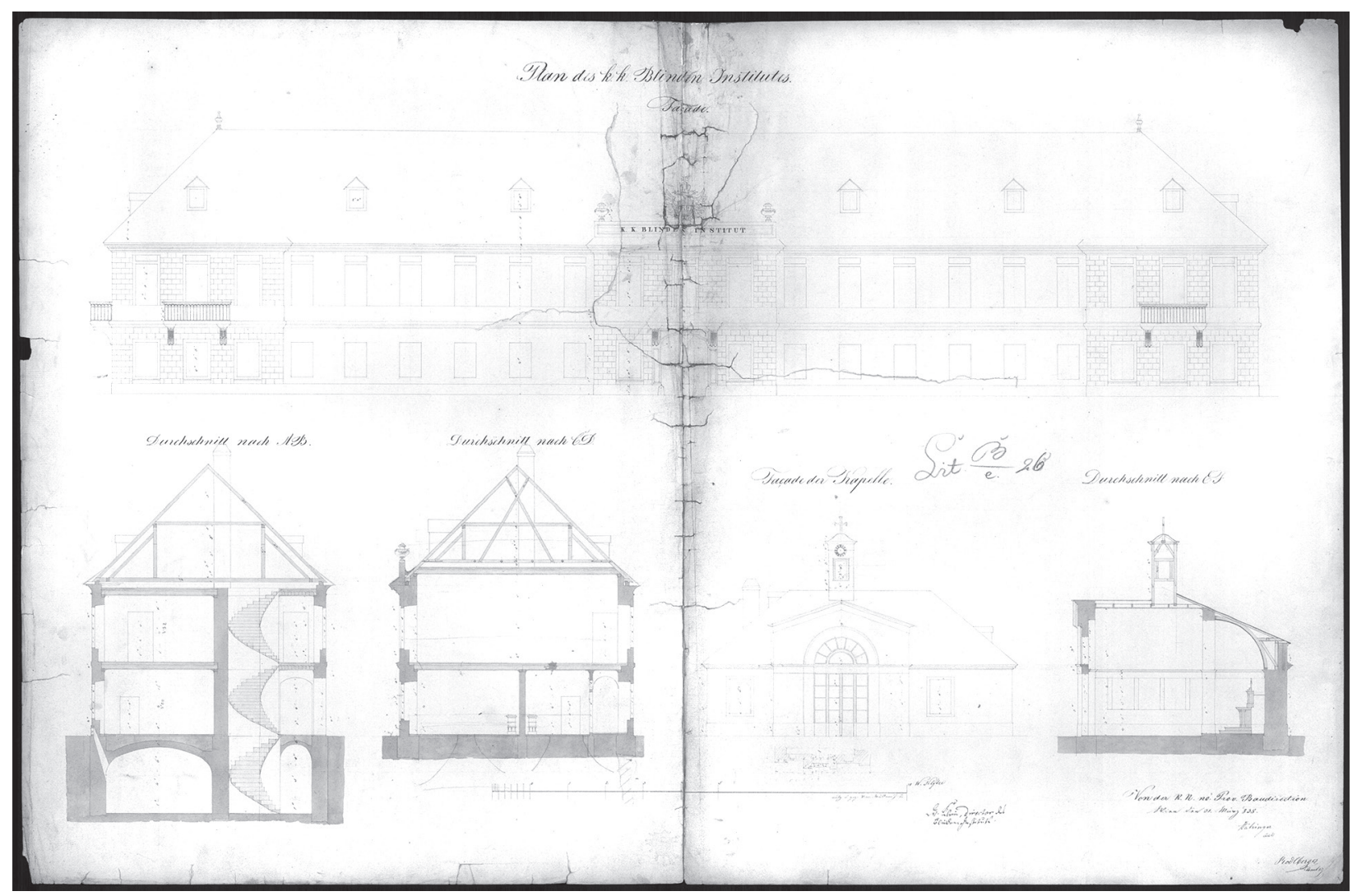

Fig. 14. Paul Hatzinger and Joseph Rodlberger: Designs for the building of the Institute for the blind (Blindeninstitut), Vienna, 1829; Österreichisches Staatsarchiv, AT-OeStA/AVA PKF PS II A-II-c/61

had only rare opportunities to express himself as an author. ${ }^{70}$

His position required him to sign off on most designs, however, it is often impossible to determine how much he contributed to them even when they bear his signature..

As far as we know, the first building he worked on upon his return to Vienna was the Veterinary Institute (Thierheilinstitut), a project on which he cooperated with engineer Johann Fischer. ${ }^{71}$ (Fig. 13) This project is usually attributed to architect Johann Amann, ${ }^{72}$ however, as the designs for the building have not survived, it is impossible to firmly determine who their author was. The central building of this wide complex is a typical example of Neoclassical public architecture in the Habsburg Monarchy, with simply articulated lateral wings and with decoration concentrated in the central avant-corps, reduced only to simple grooves cut into the façade surface on the ground floor, and with shallow Tuscan pilasters on the second and third floor.

He also worked on designs for the building of the Institute for the Blind (Blindeninstitut) in District 5 of the city of Vienna (Neubau) in 1829. (Fig. 14) He signed this design together with engineer Joseph Rodlberger, ${ }^{73}$ so we can presume he had some influence over the design process. Even more than the Veterinary Institute, this building was an example of not only utilitarian understanding of architecture, but also of the aesthetics of austerity that had been deeply rooted in the architecture of the Monarchy since the state bankruptcy in 1811, which left an especially deep impact in the design of medical and military buildings.

A far more interesting stylistic design is that of the Court and prison building (modern Landesgerichtsgebäude), which was designed in 1829 and built from 1831 to 1839 , located alongside Vienna's glacis in District 8 (Josefstadt), a structure representing one of the most monumental examples of pre-1850s public architecture in the city. (Fig. 15-17) Its stylistic design and massive rustication make it an example of the Neoclassical interpretation of architecture parlante, a type of architecture that speaks to its purpose through the use of architectural forms, 


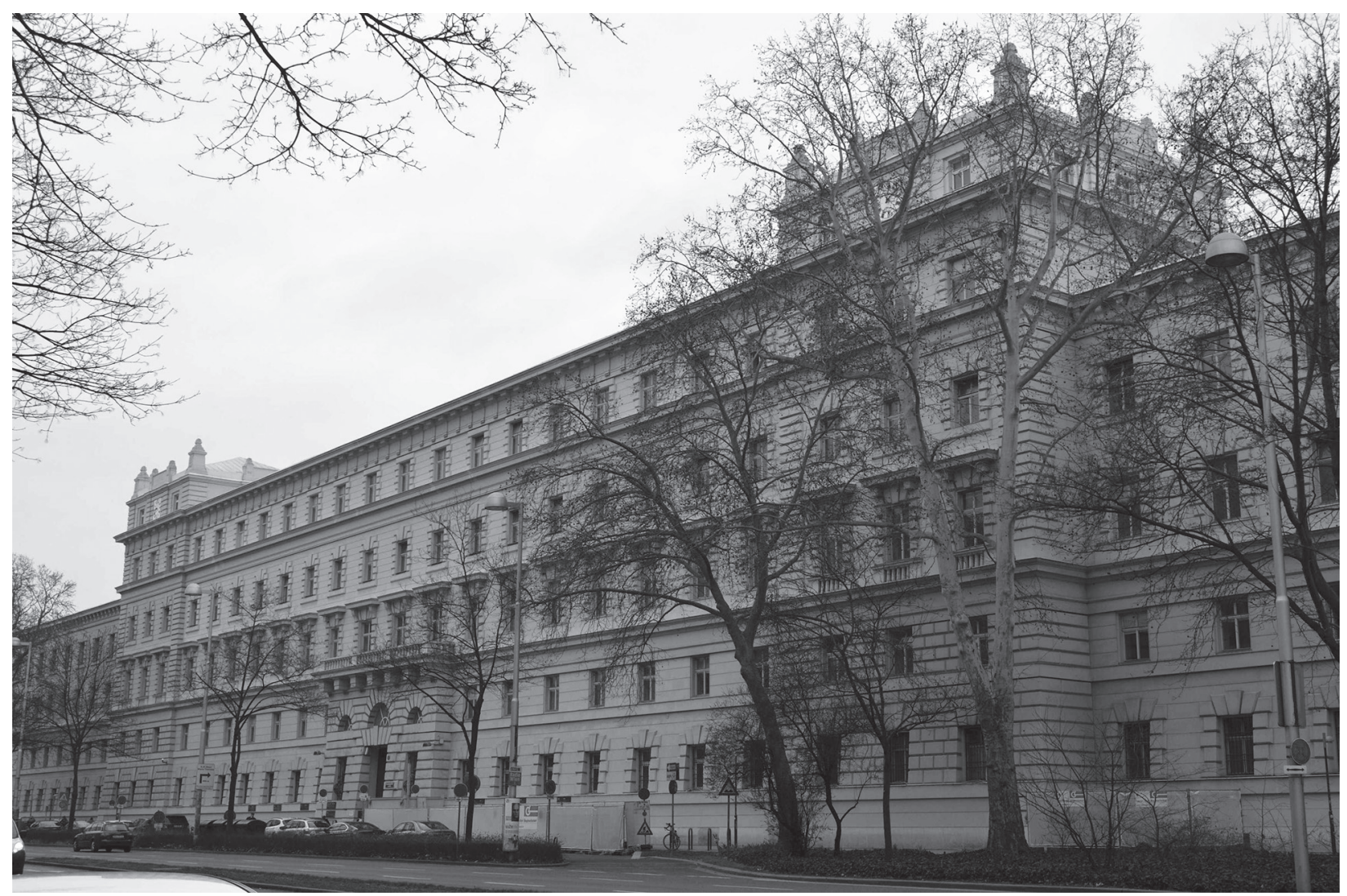

Fig. 15. Johann Fischer and possibly Paul Hatzinger: Court and prison building (Landesgerichtsgebäude), Vienna, 1831-1839 (photo by author, $11^{\text {th }}$ March 2016)

as promoted by Claude-Nicolas Ledoux. As with the other mentioned buildings, the issue exists as to whether Hatzinger played any part in its design or if Adjunkt Johann Fischer, to whom authorship is attributed ${ }^{74}$ and whose signature stands alongside Hatzinger's on the surviving designs, was the sole author. ${ }^{75}$

A similar problem with establishing authorship is found in church designs signed by Hatzinger, since other engineers' or architects' signatures also regularly appear on these designs. It was thus that Hatzinger signed a design (1830) in cooperation with Carl Pranter for the expansion of a parish church in Erdberg/Vienna from a single-nave to a triple-nave building. ${ }^{76}$ (Fig. 18) He also signed a design (1841) for a parish church in Obritz together with engineer Joseph Baumgartner, who was employed as architect in Baudirection of Lower Austria at the time. (Fig. 19) The subject was again the expansion of an existing church and the construction of a new tower. ${ }^{77}$ The new main façade and the spire were very simple, following the aforementioned aesthetics of austerity and the Biedermeier type of Neoclassicism.
Although his design was not implemented, Hatzinger played an important part in the execution of the church of St John of Nepomuk in Leopoldstadt in Vienna (1841-1846), ${ }^{78}$ a key example of early Romanticism in the architecture of the Habsburg Monarchy. (Fig. 20) Many different designs were made as part of the preparations for the construction of this church, which lasted for years. These designs show what a turning point this was in the history of Viennese architecture - when Neoclassicism, after seven decades of dominance, began to retreat and gave way to the Romantic Rundbogenstil, and even to Gothic Revival.

The Albertina in Vienna holds a very large sheet of paper with designs dating from 1838 showing six different variants for the construction of this church, made by six separate architects: Carl Pranter, Paul Hatzinger, Johann Fischer, Carl Rösner, Alois Pichl, and Paul Sprenger. ${ }^{79}$ Due to the nature of the plot where the church was built, it is understandable that there are many similarities between these designs, but there are also differences. Pranter, Rösner, Pichl, 


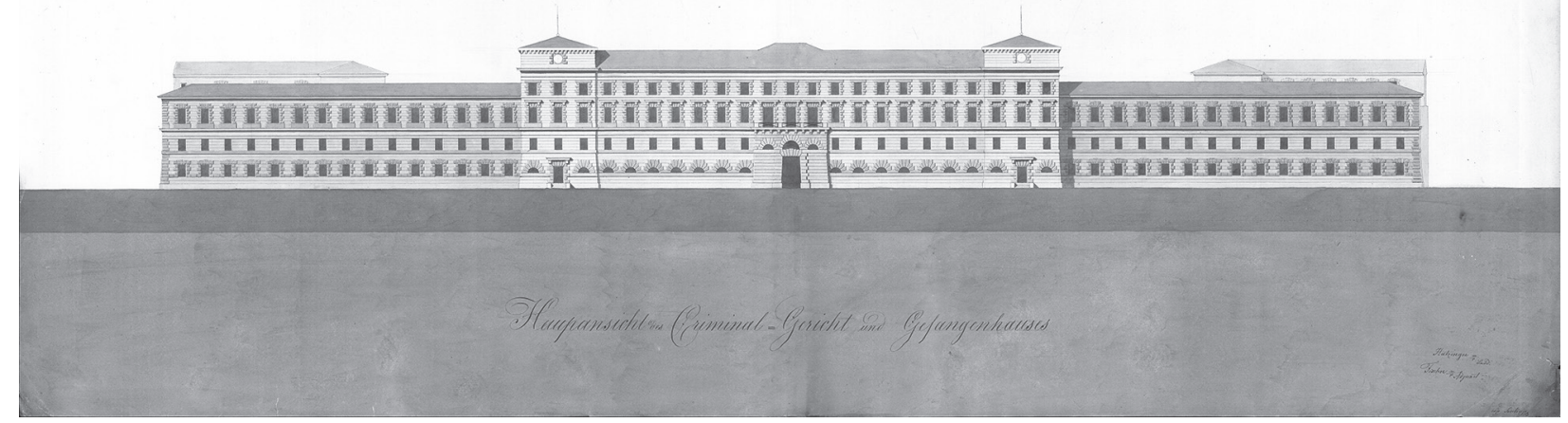

Fig: 16. Johann Fischer and possibly Paul Hatzinger: Court and prison building (Landesgerichtsgebäude), Vienna, Design for the main façade, 1829; Österreichisches Staatsarchiv, AT-OeStA/AVA PKF PS I 330

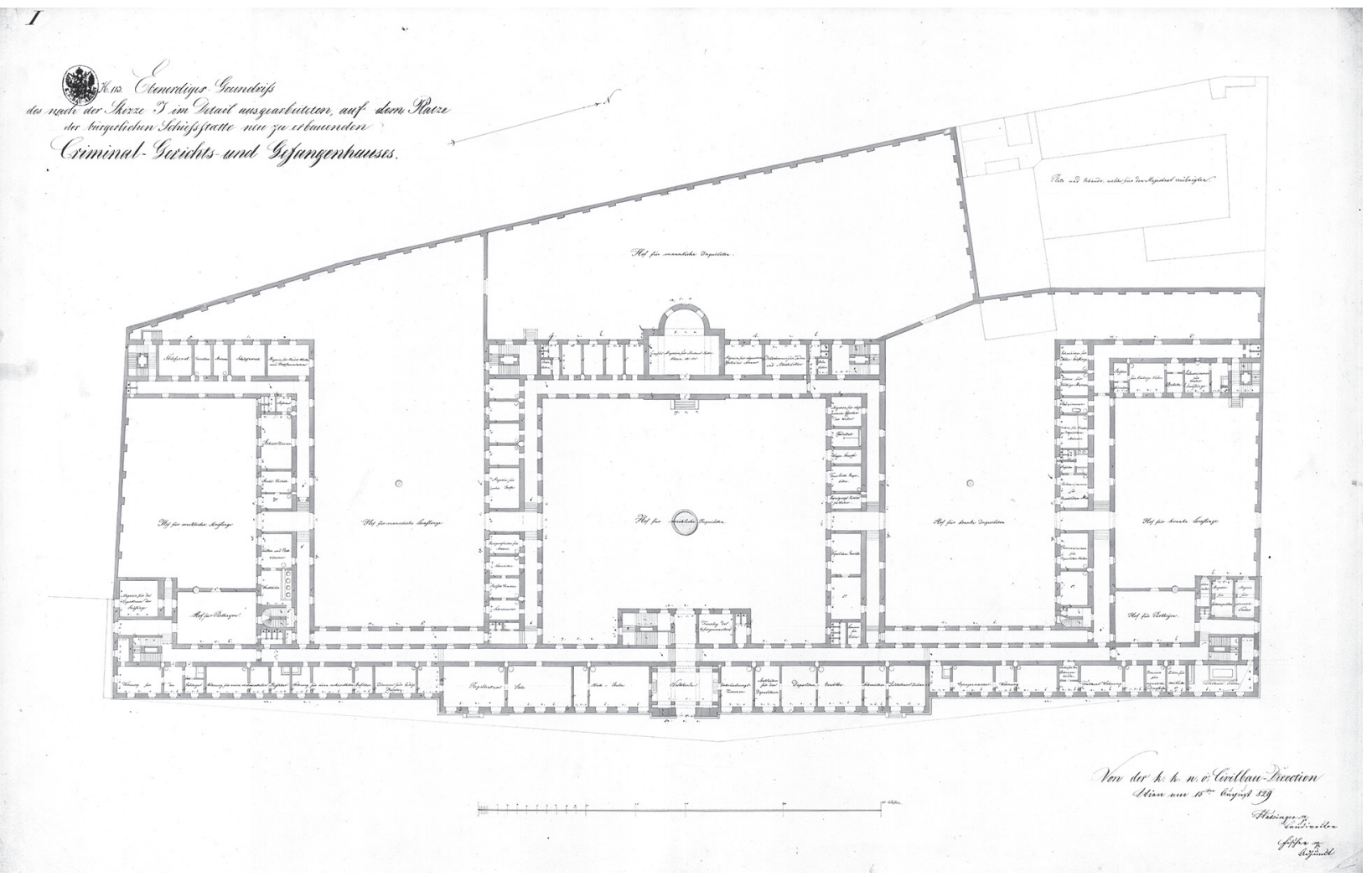

Fig. 17. Johann Fischer and possibly Paul Hatzinger: Court and prison building (Landesgerichtsgebäude), Vienna, Plan of the first floor, 1829; Österreichisches Staatsarchiv, AT-OeStA/AVA PKF PS I 330 
and Sprenger designed triple-nave churches, while Fischer and Hatzinger designed singlenave ones. Furthermore, four of the architects, Pranter, Hatzinger, Fischer, and Pichl, planned on constructing a two-tower building, while Rösner and Sprenger foresaw a single-tower one.

The majority of the designs still relied stylistically in great part on the Neoclassical architectural tradition, except for Rösner's and Sprenger's, which clearly show the inroads being made by Rundbogenstil motifs. ${ }^{80}$

Paul Hatzinger's design relies on Neoclassical stylistic vocabulary. Although his was not one of the best designs for the church in Leopoldstadt, the originality of some of the solutions he applied cannot be denied. This mostly refers to the unusual form of the spires, which look like obelisks.

Hatzinger's designs accommodated the church's position to the plot, and the front façade to the street line. A slightly prominent portico articulated with four Egyptian columns and crowned with a triangular gable dominates the main façade. A large semi-circular window stands above the main portal, undoubtedly to provide for better illumination in the interior, as the church was built inside a row of buildings. The Barrel vaulted nave has walls articulated with pairs of full columns, while the apse is shallow and semi-circular.

The church in Leopoldstadt was finally built according to Carl Rösner's design, and it marked a turning point in this architect's career, who was to become one of the most important architects of sacral buildings in the Monarchy during the 1840s and 1850s. ${ }^{81}$

Although Paul Hatzinger did not get the opportunity to express himself as the architect of this important building, several years later, the opportunity appeared for his appointment as Oberbaudirector for Lower Austria after the death of Anton Robausch. The Vienna Court Chamber (Hofkanzlei) was opposed to this appointment, as it was of the opinion that Hatzinger was too old and too sick for such an important position. Furthermore, they thought he lacked both the energy and the character to head such an important body. A very unflattering review of his work at the time partially explains the small number of his preserved designs. It was highlighted that he was neither punctual nor neat, which had

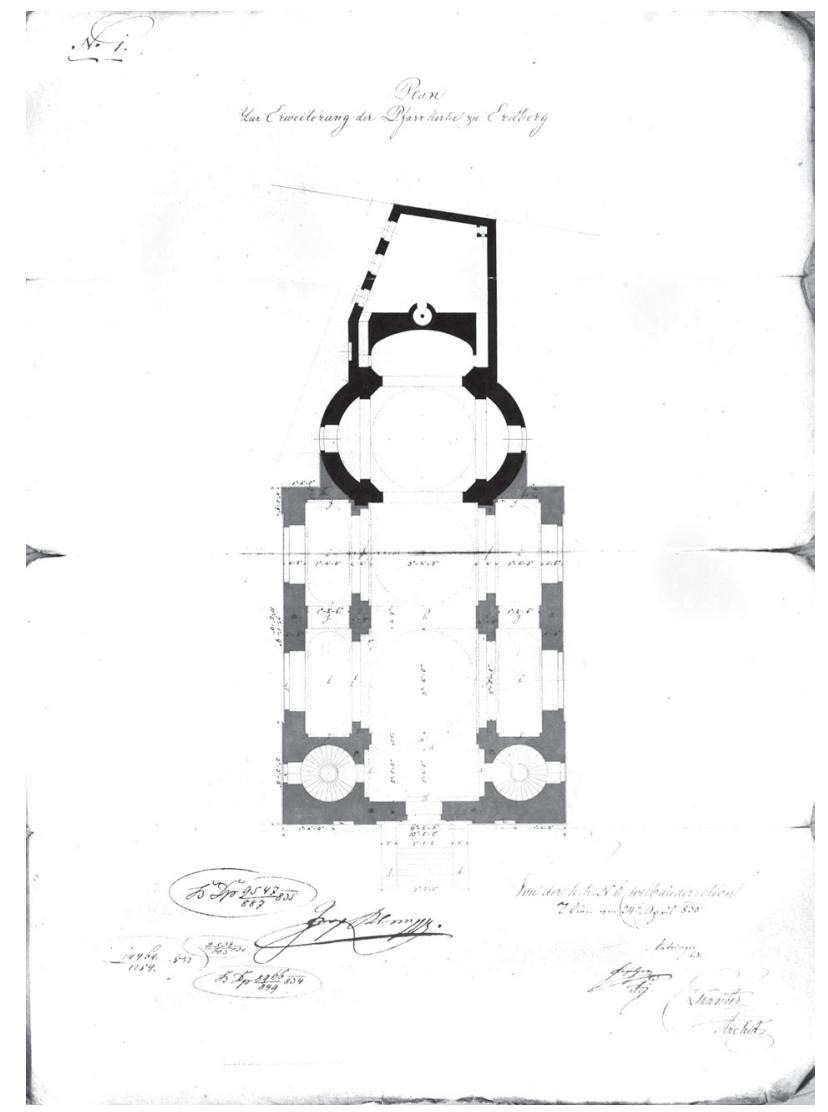

Fig. 18. Carl Pranter and Paul Hatzinger: Design for an expansion of a parish church in Erdberg, Vienna, 1830; Niederösterreichisches Landesarchiv,

St. Pölten, Kirchliche Inventare und Fassionen 1780-1939, Karton 355, Archiv für Niederösterreich,

Landesfürstliche Pfarren, Baupläne, Wien-Erdberg

resulted in his removal from a commission for state building inspection in Vienna in $1832 .^{82}$

Although the proposal to appoint him as a provisional Hofbaurat instead of Oberbaudirector was also rejected, ${ }^{83}$ due to savings and the fact that this position lacked engineers, he was still awarded this title for a short time in 1846 according to Austria's Schematismus. This was, at the time, the most prestigious title in the Monarchy, then held by the aforementioned eminent architects of the first half of the nineteenth century, Peter Nobile and Paul Sprenger, and by lessknown engineers Georg v. Frast and Ferdinand Ritter v. Mitis. ${ }^{84}$ After 1847, just one year later, he is no longer mentioned as a Hofbaurat, and is only mentioned as being taken into its service (Dienstleistung). ${ }^{85}$

He finally retired in January 1851 at the age of 68 , after having worked for almost five decades. $^{86}$ With this, all information about his later life ceases. It was not possible to determine when 


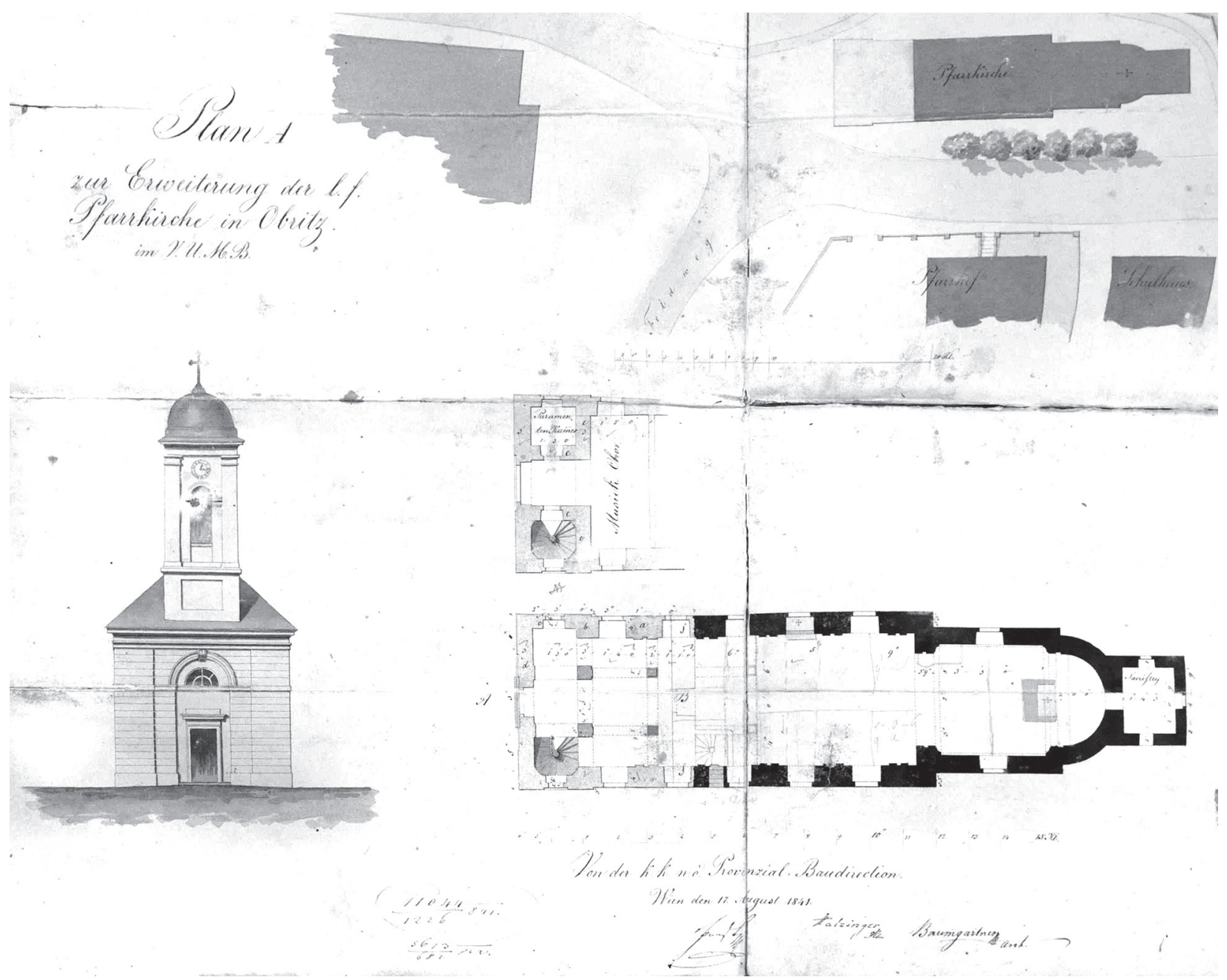

Fig. 19. Paul Hatzinger and Joseph Baumgartner: Design for the main façade of the parish church in Obritz, 1841; Niederösterreichisches Landesarchiv, St. Pölten, Kirchliche Inventare und Fassionen 1780-1939.

Karton 354, Archiv für Niederösterreich, Landesfürstliche Pfarren, Baupläne, Obritz

he died, and information about his family is very scarce. The record of the deceased at the parish of St Anastasia in Zadar only reveals that his wife's name was Anna née Ferro from Bonn, Germany. Their daughter Anna died in Zadar, ${ }^{87}$ but according to the aforementioned 1825 employment booklet, two living children remained. Data exists on only one child, his daughter Franziska Hatzinger (Vienna (?), 1814-?). She married Adolf Kasper (1809-1869), and their son Gusz- táv Kasper (Vienna, 1843 - Budapest, 1915) continued the family tradition and became a builder. After studying at the Imperial and Royal Polytechnic Institute in Vienna, he took part in the war as an Austrian naval officer in SchleswigHolstein in 1864, and in the war against Prussia. Then, in 1866, he worked on the construction of the Marseille waterfront, and after 1870 he lived in Budapest and worked for the Royal Railways. $^{88}$

\section{CONCLUSION}

The activity of the members of the Hatzinger family is an indicator of the extraordinary mobility of engineers in the Habsburg Monarchy in the eighteenth and nineteenth centuries, which led to a transfer of architectural language and form, creating a very similar type of stylistic expression in public architecture in all parts of the Monarchy usually referred to as Biedermaier Neoclassicism. 


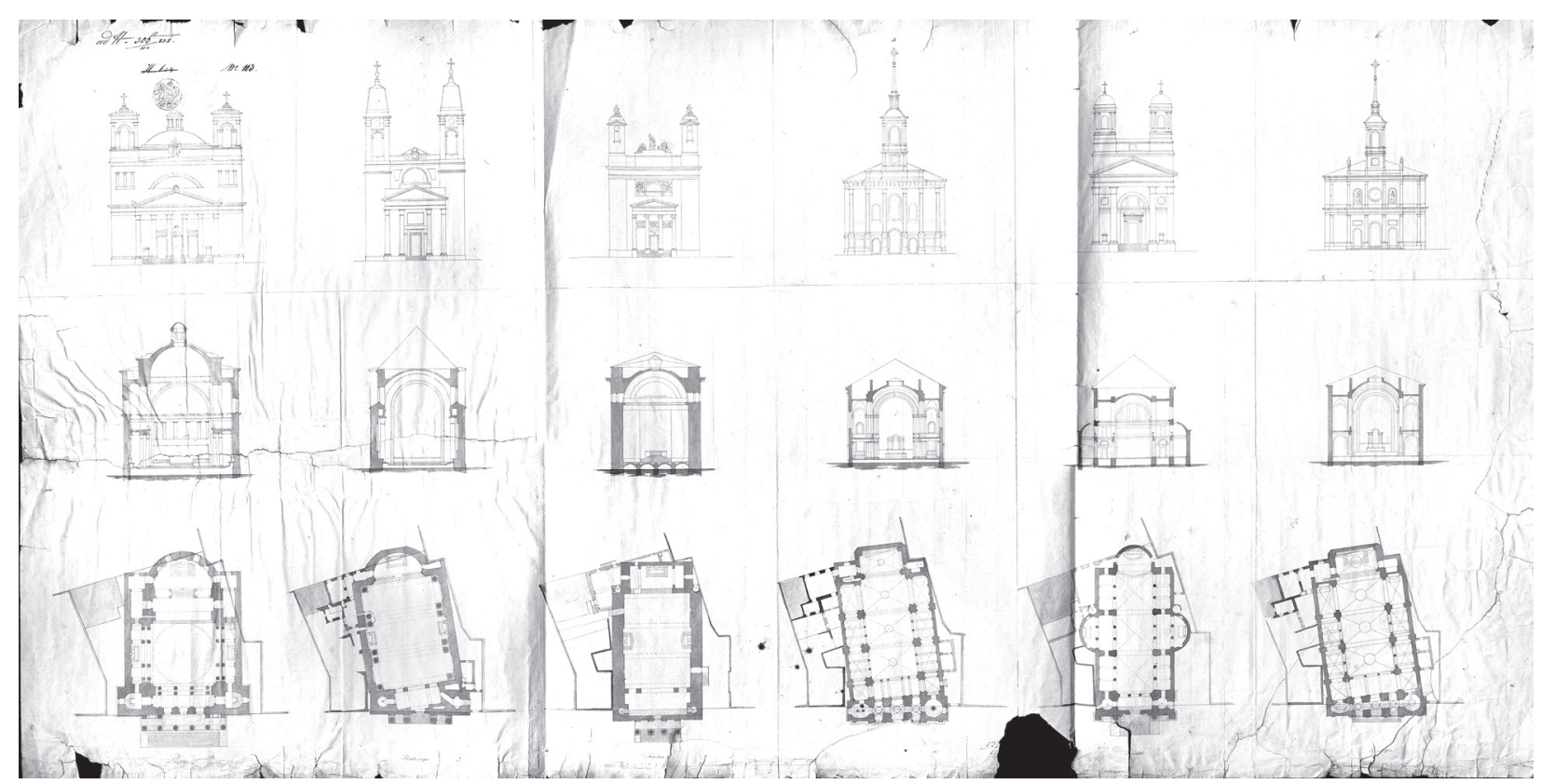

Fig. 20. Carl Pranter, Paul Hatzinger, Johann Fischer, Carl Rösner, Alois Pichl and Paul Sprenger:

Designs for the church of St John of Nepomuk in Leopoldstadt in Vienna, 1838; Albertina, Architektursammlung, Mappe 25, Umschlag 10, Nr. 1., Albertina, 7097

Like their contemporaries, they had to adapt to the economic potential of the space in which they worked and to the parameters set by contractors, which were mostly various state bodies. As they worked for public institutions and various civil engineering directorates, a large part of their work included administrative or pure engineering work, which resulted in the small number of their designs. However, due to the large number of places where the Hatzinger family members worked, the list of their projects certainly will not end with this text.

Finally, although they were not excellent builders for the most part, they represent an interesting indicator of the maintenance of the tradition of education in civil engineering within one family for a period spanning from the mid-eighteenth century to the late nineteenth century. ${ }^{89}$

\section{NOTES}

${ }^{1}$ Városi Levéltár és Kutatóintézet Székesfehérvár [Archive of the City of Székesfehérvár], Liber Baptistorum, 1730-1745 (Anyakönyv, Belvárosi Plébánia), p. 125, note dated 19 February 1734. A 1786 description of Osijek District clearly indicates that he was born in Székesfehérvár: SRŠAN, Stjepan: Kotar Osïek 1786. godine [Osijek District in the Year 1786], State Archives in Osijek, Osijek, 2002. (Grada za povijest Osijeka i Slavonije XIII) 99.

2 ScHoEN, Arnold: Székesfehérvár 18. századbeli építőmesterei, Székesfehérvári Szemle I/10-12. 1931. 3-6: 4; Schoen, Arnold: Az abai Szentháromság-templom szentélye, Székesfehérvári Szemle V/1-2. 1935. 16-24: 21-22; VoIT, Pál: Der Barock in Ungarn, Corvina, Budapest, 1971. 41; ENTz, Géza Antal: Magyarország müemlékei, Székesfehérvár, Budapest, 2009. 60, 146, 151, 154; Tóth, Nóra: Die ehemalige Jesuitenkirche zum Heiligen Johannes von Nepomuk in Székesfehérvár und ihre Freskenausstattung; Diplomarbeit, Universität Wien 2013. 27-30.

SRŠAN 2002 (see note 1), 99; ODOR, Imre: Osijek u doba cara i kralja Josipa II. 1786. godine [Osijek under the Reign of Emperor and King Joseph II in the Year 1786], Glasnik arhiva Slavonije i Baranje 4. 1997. 170-183: 180.

${ }^{4}$ State Archives in Osijek (hereinafter: HR-DAOS), Fund 500, M - V - 419/9 (534), Liber Copulatorum in Praesidio
Essekinensi ab Anno MDCCXXXIX 1736-1795, p. 118, 12 October 1760

5 Croatian State Archives (further in text HR-HDA), Fund 430, book 36, Slavonska generalkomanda [Slavonian Military Headquarters], register de anno 1762.

${ }^{6}$ This is confirmed by a contract from 1766 preserved at the Österreichisches Staatsarchiv, Vienna. AT-OeStA/KA ZSt HKR SR KzlA XIII, 120.

${ }^{7}$ HR-HDA, Fund 430, book 37, Slavonska generalkomanda [Slavonian Military Headquarters], register de anno 1763.

${ }^{\circ}$ Zapisnik Općine Osijek - Turda od 1770. do 1786. godine [Records of Osijek - Tvrda Municipality from 1770 to 1786 , ed. SRŠAn, Stjepan. Sveučilište Josipa Jurja Strossmayera u Osijeku, Historijski arhiv u Osijeku, Osijek, 1992. (Građa za povijest Osijeka i Slavonije 8) 13-15.

${ }^{9}$ OdOR 1997 (see note 3), 180.

${ }^{10}$ BösENDORFER, Josip: Vjerska organizacija u Osijeku Religious Organization in Osijek], in Zbornik Arheološkog kluba „Mursa" Osïek, Osijek, 1936. 19-23; MAŽURAN, Ive: Od turskog. do suvremenog Osijeka [From Turkish to Contemporary Osijek], Zavod za znanstveni rad HAZU u Osijeku, Gradsko poglavarstvo Osijek, Školska knjiga d. d., Zagreb, Osijek 1996. 69-78.

${ }^{11}$ BösENDORFER, Josip: Sto znademo o prvim sucima (iudices, Richter) u komorskom Osijeku? [What do We Know about 
the First Iudices in Osijek under the Hungarian Royal Chamber?], Osječki zbornik 1. 1942. 37-44: 47; MAŽURAN 1996 (see note 10), 50; SRŠAN 2002 (see note 1), 2.

${ }^{12}$ VALJaVEc, Fritz: Geschichte der deutschen Kulturbeziehungen zu Südosteuropa III. Aufklärung und Absolutismus, München 1958. (Südosteuropäische Arbeiten 43) 191; SCHUBERT, Gabriella: Das deutsche Theater in Esseg (Osijek/Eszék), Zeitschrift für Balkanologie 29/1. 2003. 90-107: 93.

${ }^{13}$ SRŠAN, Stjepan: Zemljišna knjiga grada Osijeka (Turda), 1687. - 1921. godine [Grundbuch der Stadt Osijek 1687. 1821.], Osijek, 1995. 39-40.

${ }^{14} \mathrm{He}$ is sporadically mentioned in lists of Osijek builders: LeNTIĆ-KugLI, Ivy: Prilog istraživanja osječkih graditelja 18. stoljeća [Appendix to the Research of Osijek Builders of the 18th Century], Vijesti muzealaca i konzervatora Hrvatske XXII/1. 1973. 9-21; HoRvaT, Andela: Barok u kontinentalnoj Hrvatskoj [Baroque in Continental Croatia], in Barok u Hrvatskoj [Baroque in Croatia], Sveučilišna naklada Liber, Zagreb, 1982. 1-381: 315

${ }^{15}$ Zapisnik Općine Osijek - Turda od 1745. do 1770. godine. [Records of Osijek - Turda Municipality from 1745 to 1770], ed. SRŠaN, Stjepan. Sveučilište u Osijeku. Historijski arhiv u Osijeku, Osijek, 1987. (Grada za historiju Osijeka i Slavonije 6) 255 .

16 SRŠAn 1992 (see note 8). 13-15.

17 SRŠAN 1992 (see note 8), 60.

${ }^{18}$ Matić, Vilim, Kelava, Ana: Komorska općina Osijek Gornji grad [Chamber Municipality Osijek - Upper Town]; Zapisnik gradskog vijeća Gornjeg Osijeka 26. XI. 1773. - 29. III. 1776. Records of Osijek Upper Town Council from 26th November 1773 to 29th March 1776], in Tri stoljeća kapucina u Osijeku 1703. - 2003. i općina Gornji grad do ujedinjenja 1702. - 1786. [Three Centuries of the Order of Friars Minor Capuchin in Osijek 1703 - 2003 and Upper Town Municipality until Unification 1702 - 1786], Hrvatska akademija znanosti i umjetnosti Zavod za znanstveni i umjetnički rad u Osijeku, Osijek, 2004. 338-346: 343.

${ }^{19}$ Preserved at the Croatian State Archives in Zagreb. HRHDA, Fond 661, Isusovački samostan Osijek [Jesuit Monasterv, Osijek].

${ }^{20}$ HR-DAOS, Fond 3, Komorska općina Donji Grad [Lower Town Chamber Municipality], book 6, Knjiga primitaka i izdataka Donjogradske crkve 1736.-1770., troškovi za 1763. [Ledger of the Lower Town Church 1736 - 1770, expenditures for 17637 .

${ }^{21}$ HR-DAOS, Fond 3, Komorska općina Donji Grad [Lower Town Chamber Municipality], book 6, Knjiga primitaka i izdataka Donjogradske crkve 1736.-1770., troškovi za 1763. i 1765. [Ledger of the Lower Town Church 1736 - 1770, expenditures for 1763 and 1765 ].

${ }^{22}$ Archive of Osijek's Lower Town Parish, book Essegger Unter Varoscher Kirchen Manuales über Empfang und Ausgab Anno 1766-1805.

${ }^{23}$ HR-HDA, Fond 33, Virovitička županija [Virovitica County], Box 60, file 225-1775.

${ }^{24}$ HR-HDA, Fond 33, Virovitička županija [Virovitica County], Box 65, file 301-1776; SRŠAN 1992 (see note 8), 339

${ }^{25}$ LandeKa, Marko: Gradnja crkve sv. Ivana Nepomuka u Vinkovcima [Building of the Saint John of Nepomuk Church in Vinkovci], Godišnjak Ogranka Matice hrvatske Vinkovci 10. 1992. 125-134: 130; LANDEKa, Marko: Dokumenti za povijest Vinkovaca u 18. stoljeću [Documents on the History of Vinkovci in the $18^{\text {th }}$ Century], Godišnjak Ogranka Matice hrvatske Vinkovci 20. 2002. 163-205: 196-200.

${ }^{26}$ His name is mentioned among the workers employed to build the fortress in 1766. Erinnerung an die Mitglieder der Arader Fortifikactionsbau-Enterprise. Wiener Zeitung $92 .\left(18^{\text {th }}\right.$ November) 1786. 2827

${ }^{27}$ Cvitanović, Đurdica: Palača srijemske županije u Vukovaru [The Syrmia County Palace in Vukovar], Radovi Instituta za povijest umjetnosti 22. 1998. 108-119; KARAČ, Zlatko: Urbanistički razvoj i arhitektonska baština Vukovara od baroka do novijega doba (1687-1945) [The Urban Development and Architectural Heritage of Vukovar - from the Baroque Period to the Second Half of the $20^{\text {th }}$ Century $\left.(1687-1945)\right]$, in Vukovar, vjekovni hrvatski grad na Dunavu [Vukovar - the Eternal Croatian City on the Danube], Nakladna kuća "Dr. Feletar," Zagreb, 1994. 267-299: 274.

${ }^{28}$ The author of the monograph article about the palace mentions Hatzinger's signature as well, but it can no longer be traced. CVITANOVIĆ 1998 (see note 27), 113.

${ }^{29}$ HR-DAOS, Fond 500, book M-U-536m, Sillabus Defunctorum In Praesidio Essekinensi Allodys et Trans Dravum ab Anno MDCCXXXIX (1739 - 1795), dated 17 November 1768.

${ }^{30}$ HR-DAOS, Fond 500, M - R- 415/5 (529). Liber Baptisatorum in Praesidio Essekinensi ab anno MDCCXXXIX (1739-1795). The names are transcribed exactly as they are listed in the birth register.

31 BöSENDORFER 1942 (see note 11), 47.

32 SRŠAn 1992 (see note 8), 433.

${ }^{33}$ Hofbauer, Carl: Die Alservorstadt mit den ursprünglichen Besitzungen der Benediktinerabtei Michelbeuern am Wildbache Als. Historisch - Topographische Skizzen zur Schilderung der alten Vorstädte Wiens, Verlag, Druck und Papier von Leopold Sommer, Vienna, 1861. 44.

${ }^{34}$ GATTI, Friedrich: Geschichte der $k$. $k$. Ingenieur- und k. k. Genie-Akademie 1717 - 1869., in Commission bei Wilhelm Braumüller, K. und K. Hof- und UniversitätsBuchhandler,Vienna, 1901.

${ }^{35}$ GATTI 1901 (see note 34), 374. "Hatzinger. Heinrich. 14 Jahre alt. Geboren zu Eszek. Vater ist Baumeister. Eingetheilt am 1. Jun. Kostgeher pr. 300 fl.; seit 16. April 1793. in die Mikos'sche Stiftung übersetzt. Am 1. Nov. 1793. Cadet im Ing. - Corps. 1805. Hptm." Same in AT-OeSTA, Kriegsarchiv, Militär-Schulen, Technische Militärakademie in Wien bzw. Mödling, box 738 .

${ }^{36}$ Hof- und Staats- Schematismus der röm. kaiserl. auch kaiserl. königl. und erzherzoglichen Haupt- und ResidenzStadt Wien, gedruckt und zu finden bey Joseph Gerold, Vienna. 1797. 98.: Ibid. 1798. 96.

${ }^{37}$ W AGNER, Walter: Der Architekturunterricht außerhalb der Kunstakademien in Mitteleuropa vom Beginn des 16. bis zur Mitte des 19. Jahrhunderts, Architectura. Zeitschrift für Geschichte der Baukunst - Journal of the History of Architecture 10. 1980. 58-91: 82.

${ }^{38}$ WAGNER 1980 (see note 37), 81.

${ }^{39}$ Verfassung der $k$. $k$. Ingenieurs-Academie in Wien, gedruckt bey Georg Ueberreuter, k. k. privil. Buchdrucker, Vienna, 1814. 9, 27-28, 31-32.

${ }^{40}$ ZatLoukal. Pavel: Architecture of the Nineteenth Century, Prague Castle Administration, Dada, Prague, 2001. 121, 188-190.

${ }^{41}$ Novák, Václav: Pevnostním městem Josefovem, Městský úřad v Jaroměři, Klub přátel Josefova, Jaroměř, 2000. 16; Mertlíková, Olga: Pevnost Josefov, Městské muzeum v Jaromeři, Jaroměř, 2008. no indication of page number.

${ }^{42}$ Romañák, Andrej: Pevnost Terezín a její místov dějinách fortifikačního stavitelství, Severočeské nakladatelství, Památník Terezín, 1972. 126; VотоČEK, Otakar, KostKové, Zdeňka: Terezín, Odeon, Prague, 1980. 52-53; Petrasová, Tatána: Architektura „státního" klasicismu, palladiánského neoklasicismu a počátků romantického historismu, in Dějiny Českého Výtvarného Umění III/1, 1780/1890, Academia, Prague 2001. 28-60: 30-31; KuPKA, Vladimír, RáKosNíková, Vladimíra, SmutnÝ, Jiř́, Tothová, Jolana: Pevnost Terezín. Kulturní statek Ceské republiky navrhovaný $k$ zápisu na Seznam světového kulturního a př́rodního dědictví UNESCO, Národní památkový ústav, Prague, 2010. 25.

${ }^{43}$ This is attested primarily by the student's books used at the Engineering Academy. WeIss von Schleussenburg, Franz: Lehrbuch der Baukunst zum Gebrauche der K. K. Ingenieurs-Akademie, Verlegt von der k. k. Ingenieurs-Akademie, Vienna, 1830. 270

${ }^{44}$ The plan from 1801 reads: "Grundrisse, Profile, Fassaden von dem in der Richtung der Weihburggasse durch einen Teil des Seilerstätter Artilleriezeughauses, dann den Rem- 
part der Courtine zwischen den Bastions Nummer III und IV neu durchzuführen angetragenen vollkommenen Stadttores allhier in Wien, samt der über den Hauptfestungsgraben leitenden Brücke, der Glacisdurchfahrt und den auch neu zu erbauenden zwei inneren Toren und äußeren Wachthäusern." AT-OeStA/KA KPS KS G VII, 1920.

${ }^{45}$ Geschichte der Kämpfe Oesterreichs. Kriege unter der Regierung des Kaisers Franz, Krieg 1809., III. Band, Neumarkt - Ebelsberg - Wien, Verlag von L. W. Seidel \& Sohn, Vienna, 1909.516

${ }^{46}$ Ibid., 519

${ }^{47}$ GATTI 1901 (see note 34), 458.

${ }^{48}$ GATTI 1901 (see note 34), 461

${ }^{49}$ GaTTI 1901 (see note 34), 397. "Hatzinger, Paul, 14 Jahre Alt. Geboren zu Eszék. Vater ist Baumeister. Eingetheilt am 3. Jul. Kostgeher pr. 315 fl. Am 1. Jun 1798 ausgetreten." Same in OeSTA, Kriegsarchiv, Militär-Schulen, Technische Militärakademie in Wien bzw. Mödling, box 738.

50 Niederösterreichisches Landesarchiv, Niederösterreichische Regierung (further in text NL, NÖ Reg), HS 68/4, Statusbuch der k.k. niederösterreichischen Civil-Baudirektion 1825. The document obtained by courtesy of Mag. Günter Marian from Niederösterreichisches Landesarchiv.

${ }^{51}$ Schematismus der kais. königl. Armée für das Jahr 1810., Vienna, 1810. 334.; WAGNER 1980 (see note 37), 82.

${ }^{52}$ NL, NÖ Reg, HS 68/4, Statusbuch der k.k. niederösterreichischen Civil-Baudirektion 1825.; Paul Hatzinger was registered as second class district engineer in the Town of Sambor in Galicia in the category Genie- und Bau-Personale auf dem Lande k. k. galizische Landes-Baudirekzion. According to: Schematismus des Königreiches Galizien und Lodomerien für das Jahr 1818, Gedruckt und zu haben bey Joseph Johann Piller, Lemberg, 1818. 164; STAGLičić, Marija: Klasicizam u Zadru [Neoclassicism in Zadar], Institut za povijest umjetnosti, Zagreb, 1996. 70.

3 AT-OeStA/FHKA SUS KS, Ra 0330/1-2.

${ }^{54}$ NL, NÖ Reg., HS 68/4, Statusbuch der k.k. niederösterreichischen Civil-Baudirektion 1825.; State Archives in Zadar (further in text HR-DAZD) HR-DAZD-88, Vlada/Namjesništvo za Dalmaciju [Government of Dalmatia], box $\mathrm{Nr} 74$. ., R. N. 1819.. file 10/1-199.

55 PIPLOVIĆ, Stanko: Život i djelo inž. Petra Pekote [Life and Work of the Engineer Petar Pekota], Zadarska revija 1-2. 1987. 107-119: 112.

${ }^{56}$ Piplović 1987 (see note 55), 109.

${ }^{57}$ HR-DAZD-88, Vlada/Namjesništvo za Dalmaciju [Government of Dalmatia], book 645, Indice Politico dell'anno 1819.

${ }^{58}$ STTAGLIČIĆ 1996 (see note 52), 42-43; STAGLIČIĆ, Marija: Graditeljstvo Zadra od klasicizma do secesije [Architecture of Zadar from Neoclassicism till Art-Nouveau], Institut za povijest umjetnosti, Zagreb, 2013. 40, 43.

${ }^{59}$ Stagličić 1996 (see note 52), 49, 51; STAGLIČIĆ 2013 (see note 58), 41,43 .

60 STAGLIČIĆ 2013 (see note 58), 29

${ }^{61}$ Stagličić 1996 (see note 52), 37-38; Stagličić, Marija: Urbanistički razvoj grada i likovne umjetnosti u Zadru (1800. - 1914.) [The Urban Development of the City and the Visual Arts in Zadar (1800-1914)], in Zadar za austrijske uprave [Zadar during Austrian Rule] (Prošlost Zadra, book IV), Matica Hrvatska - ogranak u Zadru, Zadar, 2011. 259-396: 276; PIPLOVIĆ, Stanko: Graditeljstvo u Dalmaciji za francuske uprave [Architecture in Dalmatia under French rule], Adrias 18. 2012. 75-102: 99.

${ }^{62}$ KeČKEMET. Duško, Vicko Andrić, arhitekt $i$ konzervator (1793-1866) [Vicko Andrić, Architect and Conservator 1793-1866], Regionalni zavod za zaštitu spomenika kulture, Književni krug, Split, 1993. 29-36; PIPLOVIĆ, Stanko: Regulacijski plan Splita Francesca Locatija iz godine 1862. [The Split Regulation Plan of 1862 by Francesco Locati], Kulturna baština 37. 2011. 173-190: 180.

${ }^{63}$ HR-DAZD-88, Vlada/Namjesništvo za Dalmaciju [Government of Dalmatia], book 649, Index Polittico for 1821;
Savitz Nossan, Stjepan: Josip Kajetan Knežić 1786-1848, Senjski zbornik IV. 1970. 192-204: 194-195; STAGLIČIĆ 1996 (see note 52), 10 .

${ }^{64}$ HR-DAZD-493, Family archive Pecota, box 15.

${ }^{65}$ HR-DAZD-88, Vlada/Namjesništvo za Dalmaciju [Government of Dalmatia], box 125, file XI/3., 1252 ex 1823.

${ }_{66}$ AT-OeStA/AVA PKF PS I 1325.

${ }^{67}$ AT-OeStA/KA KPS LB K VII i, 42 E.

${ }^{68}$ HR-DAZD-88, Vlada/Namjesništvo za Dalmaciju [Government of Dalmatia], box 22, Praesidium, document no. 137, ex 1819

${ }^{69}$ NL, NÖ Reg, HS 68/4, Statusbuch der k.k. niederösterreichischen Civil-Baudirektion 1825.

${ }^{70} \mathrm{He}$ is also mentioned as Baudirector for Lower Austria in the most important nineteenth century lexicons, but the same sources make no mention of his work: TschISCHKA, Franz: Kunst und Alterthum in dem österreichischen Kaiserstaate, Vienna, 1836. 363; WuRZBACH, Constant von: Biographisches Lexicon des Kaiserthums Oesterreich 8, Vienna, 1862. 53.

${ }^{71}$ Wien. Wiener Zeitung $\left(265,18^{\text {th }}\right.$ November) 1823. 1.

${ }^{72}$ Wagner-Rieger, Renate: Wiens Architektur im 19. Jahrhundert, Oesterreichischer Bundesverlag für Unterricht, Wissenschaft und Kunst, Vienna, 1970. 59.

${ }^{73}$ AT-OeStA/AVA PKF PS II A-II-c/61.

${ }^{74}$ Wagner-RIEGer 1970 (see note 72 ), 86.

${ }^{75}$ AT-OeStA/AVA PKF PS I 330.

${ }^{76}$ It appears that Hatzinger and Pratner did not design the new main facade of the church, which was built according to an 1827 design by an unnamed Hofbaurath: SCHIEBINGER, Michael: Studien zum Sakralbau des Vormärz im Wiener Raum, Diplomarbeit, Universität Wien, Vienna, 2012. 54-56.

7 SCHIEBINGER 2012 (see note 76). 64-65.

${ }^{78}$ Realis (R. v. CoECKELBERGHe-Dützele, Gerhard Robert Walter): Die landesfürstliche Pfarrkirche zum heil. Johann von Nepomuck in der Praterstrasse in Wien. Bei Gelegenheit der Grundsteinlegung und Einweihung des neuen Gotteshauses, Vienna, 1846. 9; SCHIEBINGER 2012 (see note 76), 36.

${ }^{79}$ Mappe 25, Umschlag 10, Nr. 1, Albertina, 7097.

${ }^{80}$ Generally speaking, Roesner and Sprenger had very similar solutions for the form, and they both started using a rectangular chancel.

${ }^{81}$ More on this church in REDL, Dagmar: Zwei Pionierbauten des romantischen Historismus - Die beiden JohannNepomuk-Kirchen Karl Rösners in Wien-Leopoldstadt und Wien-Meidling, Diplomarbeit, Institut für Kunstgeschichte, Vienna, 1997.-1998.; REDL, Dagmar: Karl Rösner (1804-69), Ein Wiener Architekt von europäischem Format, Österreichische Zeitschrift für Kunst und Denkmalpflege LII-3/4. 1998. $550-574$.

${ }^{82}$ AT-OeStA I/1. AVA. Hofkanzlei. box 132, 1845.. Nr. 170-1845., Presidiale, Note an S. H.W. Freyherr Karl Friedrich von Kübeck, Hofkammer Präsidium in Wien.

${ }^{83}$ Ibid.

${ }^{84}$ Hof- und Staats-Schematismus des österreichischen Kaiserthums, I. Theil. Vienna, 1846. 226; Handbuch des Königreiches Böhmen für das Jahr 1846., Prague, 1846. 14-15; NL, Archiv für Niederösterreich, Niederösterreichisches Landesregierung, book 55, Präs., 1845, Hatzinger.

${ }^{85}$ Hof- und Staats-Schematismus des österreichischen Kaiserthums, I. Theil. Vienna, 1847. 232; Hof- und Staats-Schematismus des österreichischen Kaiserthums, I. Theil. Vienna, 1848. 235

${ }^{86}$ Verordnungsblatt für die Verwaltungszweige des österreichischen Handelsministeriums, I. 6. (14 ${ }^{\text {th }}$ January 1851). 34.

${ }_{87}^{8}$ STAGLIČIĆ 1996 (see note 52). 81.

88 Thurnay Béláné Schulek, Vilma: Termő Csipkebokor, Ordass Lajos Baráti Kör kiadó, 2009. 14-16; I would like to thank Mrs Thurnay Béláné, Vilma Schulek for the information about Paul Hatzinger's heirs, as well as for the photos of portraits of this builder and his wife.

${ }^{89}$ This work has been fully supported by the Croatian Science Foundation under project 4153 Croatia and Central Europe: Art and Politics in the Late Modern Period (1780-1945). 